OECD/G20 Base Erosion and Profit Shifting Project

\title{
Preventing the Granting of Treaty Benefits in Inappropriate Circumstances
}

ACTION 6: 2014 Deliverable

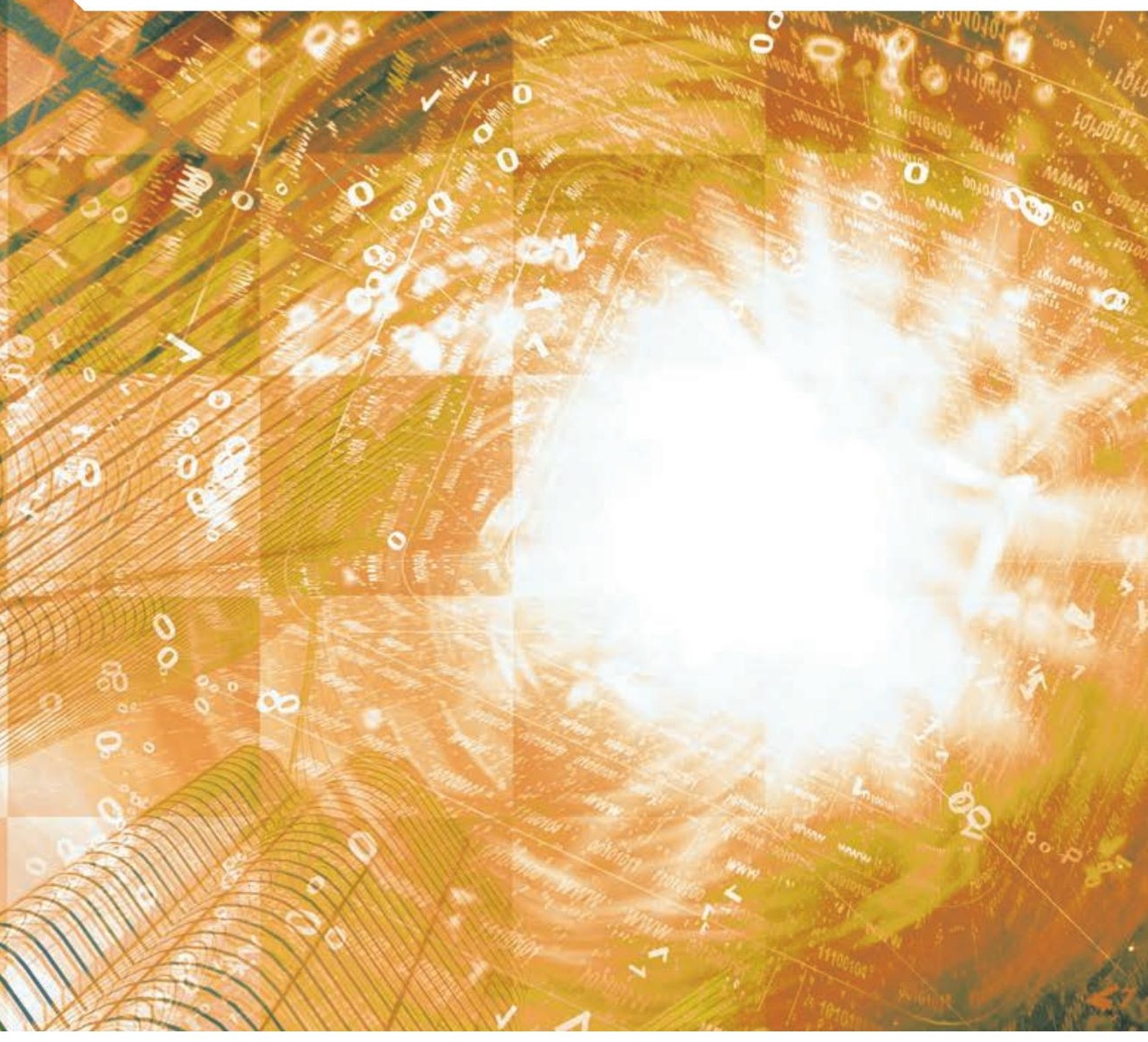

(2)》OECD 

OECD/G20 Base Erosion and Profit Shifting Project

\section{Preventing the Granting of Treaty Benefits in Inappropriate Circumstances}

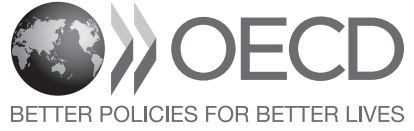


This document and any map included herein are without prejudice to the status of or sovereignty over any territory, to the delimitation of international frontiers and boundaries and to the name of any territory, city or area.

\section{Please cite this publication as:}

OECD (2014), Preventing the Granting of Treaty Benefits in Inappropriate Circumstances, OECD/G20 Base Erosion and Profit Shifting Project, OECD Publishing. http://dx.doi.org/10.1787/9789264219120-en

ISBN 978-92-64-21906-9 (print)

ISBN 978-92-64-21912-0 (PDF)

Series: OECD/G20 Base Erosion and Profit Shifting Project

ISSN 2313-2604 (print)

ISSN 2313-2612 (online)

Photo credits: Cover $@$ archerix / Fotolia.

Corrigenda to OECD publications may be found on line at: www.oecd.org/about/publishing/corrigenda.htm.

(C) OECD 2014

You can copy, download or print OECD content for your own use, and you can include excerpts from OECD publications, databases and multimedia products in your own documents, presentations, blogs, websites and teaching materials, provided that suitable acknowledgment of the source and copyright owner is given. All requests for public or commercial use and translation rights should be submitted to rights@oecd.org. Requests for permission to photocopy portions of this material for public or commercial use shall be addressed directly to the Copyright Clearance Center (CCC) at info@copyright.com or the Centre français d'exploitation du droit de copie (CFC) at contact@cfcopies.com. 


\section{Foreword}

Addressing base erosion and profit shifting (BEPS) is a key priority of governments around the globe. In 2013, OECD and G20 countries, working together on an equal footing, adopted a 15-point Action Plan to address BEPS. The Action Plan aims to ensure that profits are taxed where economic activities generating the profits are performed and where value is created. It was agreed that addressing BEPS is critical for countries and must be done in a timely manner, not least to prevent the existing consensusbased international tax framework from unravelling, which would increase uncertainty for businesses at a time when cross-border investments are more necessary than ever. As a result, the Action Plan provides for 15 actions to be delivered by 2015, with a number of actions to be delivered in 2014 .

The OECD Committee on Fiscal Affairs (CFA), bringing together 44 countries on an equal footing (all OECD members, OECD accession countries, and G20 countries), has adopted a first set of seven deliverables described in the Action Plan and due in 2014. This report is part of these deliverables and is an output of Action 6.

Developing countries and other non-OECD/non-G20 economies have been extensively consulted through regional and global fora meetings and their input has been fed into the work. Business representatives, trade unions, civil society organisations and academics have also been very involved through opportunities to comment on discussion drafts. These have generated more than 3500 pages of comments and were discussed at five public consultation meetings and via three webcasts that attracted more than 10000 viewers.

The first set of reports and recommendations, delivered in 2014, addresses seven of the actions in the BEPS Action Plan published in July 2013. Given the Action Plan's aim of providing comprehensive and coherent solutions to BEPS, the proposed measures, while agreed, are not yet formally finalised. They may be affected by some of the decisions to be taken with respect to the 2015 deliverables with which the 2014 deliverable will interact. They do reflect consensus, as of July 2014, on a number of solutions to put an end to BEPS. 
The adoption of this first set of deliverables and the implementation of the relevant measures by national governments mean that: hybrid mismatches will be neutralised; treaty shopping and other forms of treaty abuse will be addressed; abuse of transfer pricing rules in the key area of intangibles will be greatly minimised; and country-by-country reporting will provide governments with information on the global allocation of the profits, economic activity and taxes of MNEs. Equally, OECD and G20 countries have agreed upon a report concluding that it is feasible to implement BEPS measures through a multilateral instrument. They have also advanced the work to fight harmful tax practices, in particular in the area of IP regimes and tax rulings. Finally, they have reached a common understanding of the challenges raised by the digital economy, which will now allow them to deepen their work in this area, one in which BEPS is exacerbated.

By its nature, BEPS requires co-ordinated responses. This is why countries are investing time and resources in developing shared solutions to common problems. At the same time, countries retain their sovereignty over tax matters and measures may be implemented in different countries in different ways, as long as they do not conflict with countries' international legal commitments. 


\section{Table of contents}

Abbreviations and acronyms ..........................................................................................

Executive summary .......................................................................................................9

Introduction.......................................................................................................................17

A. Treaty provisions and/or domestic rules to prevent the granting of treaty benefits in inappropriate circumstances .................................20

1. Cases where a person tries to circumvent limitations provided by the treaty itself .................................................................20

a) Treaty shopping ...................................................................20

i) Limitation-on-benefits rule ................................................24

ii) Rules aimed at arrangements one of the principal purposes of which is to obtain treaty benefits....

b) Other situations where a person seeks to circumvent treaty

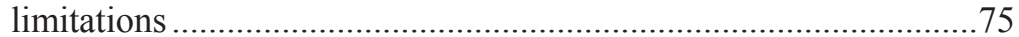

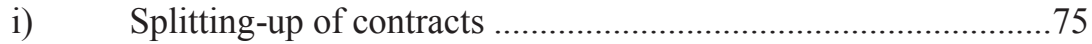

ii) Hiring-out of labour cases................................................75

iii) Transactions intended to avoid dividend characterisation ..........76

iv) Dividend transfer transactions ..............................................76

v) Transactions that circumvent the application of Article 13(4)....78

vi) Tie-breaker rule for determining the treaty residence of dual-resident persons other than individuals...........................79

vii) Anti-abuse rule for permanent establishments situated in third States

2. Cases where a person tries to abuse the provisions of domestic tax law using treaty benefits

B. Clarification that tax treaties are not intended to be used to generate double non-taxation

C. Tax policy considerations that, in general, countries should consider before deciding to enter into a tax treaty with another country. 

Abbreviations and acronyms

BEPS Base erosion and profit shifting

CFC Controlled foreign company

CIV Collective investment vehicles

GAAR General anti-avoidance rule

EU European Union

LOB Limitation-on-benefits

OECD Organisation for Economic Co-operation and Development

PE Permanent establishment

PPT Principal purposes test

REIT Real Estate Investment Trust

RIC Regulated Investment Company

VCLT Vienna Convention on the Law of Treaties 



\section{Executive summary}

Action 6 of the BEPS Action Plan identified treaty abuse, and in particular treaty shopping, as one of the most important sources of BEPS concerns. It called for work to be carried on in order to:

A. Develop model treaty provisions and recommendations regarding the design of domestic rules to prevent the granting of treaty benefits in inappropriate circumstances.

B. Clarify that tax treaties are not intended to be used to generate double non-taxation.

C. Identify the tax policy considerations that, in general, countries should consider before deciding to enter into a tax treaty with another country.

This report includes the proposed changes to the OECD Model Tax Convention that are the results of that work. These changes reflect the agreement that the OECD Model should be amended to include provisions to prevent treaty abuse. Given the variety of approaches, a number of treaty provisions recommended in this report offer alternatives and a certain degree of flexibility. There is agreement, however, that these alternatives aim to reach a common goal, i.e. to ensure that States incorporate in their treaties sufficient safeguards to prevent treaty abuse, in particular as regards treaty shopping. For that reason, the report recommends a minimum level of protection that should be implemented (see below).

Indeed, when examining the model treaty provisions included in this report, it is important to note that these are model provisions that need to be adapted to the specificities of individual States and the circumstances of the negotiation of bilateral conventions. For example, some countries may have constitutional or EU law restrictions that prevent them from adopting the exact wording of the model provisions that are recommended in this report, some countries may have domestic anti-abuse rules or their courts may have developed various interpretative tools that effectively prevent some of the treaty abuses described in this report and the administrative capacity of some countries may prevent them from applying certain detailed anti-abuse rules and require them to adopt more general anti-abuse provisions. 
Whilst there is agreement that the minimum level of protection against treaty abuse, including treaty shopping, described in this Executive summary and in paragraph 14 of the report should be included in the OECD Model, it is recognised that further work will be needed with respect to the precise contents of the model provisions and related Commentary included in Section A of this report, in particular the LOB rule. Further work is also needed with respect to the implementation of the minimum standard and with respect to the policy considerations relevant to treaty entitlement of collective investment vehicles (CIVs) and non-CIV funds. The model provisions and related Commentary included in Section A of this report should therefore be considered as drafts that are subject to improvement before their final versions are released in September 2015.

\section{A. Develop model treaty provisions and recommendations regarding the design of domestic rules to prevent the granting of treaty benefits in inappropriate circumstances}

Section A of the report includes recommendations intended to prevent the granting of treaty benefits in inappropriate circumstances. For that purpose, a distinction is made between two types of cases:

1. Cases where a person tries to circumvent limitations provided by the treaty itself.

2. Cases where a person tries to circumvent the provisions of domestic tax law using treaty benefits.

Since the first category of cases involves situations where a person seeks to circumvent rules that are specific to tax treaties, it is recommended to address these cases through anti-abuse rules to be included in treaties. The situation is different with respect to the second category of cases: since these cases involve the avoidance of domestic law, they cannot be addressed exclusively through treaty provisions and require domestic anti-abuse rules, which raises the issue of possible conflicts between these domestic rules and the provisions of tax treaties.

\section{Cases where a person tries to circumvent limitations} provided by the treaty itself

The recommendations for new treaty anti-abuse rules included in the report first address treaty shopping strategies through which a person who is not a resident of a Contracting State attempts to obtain benefits that a tax treaty grants to a resident of that State. Additional recommendations address other strategies aimed at satisfying different treaty requirements with a view to obtain inappropriately the benefit of certain provisions of tax treaties. 
a) Recommendations related to treaty shopping

The report recommends that a three-pronged approach be used to address treaty shopping arrangements:

- First, it is recommended that treaties include, in their title and preamble, a clear statement that the Contracting States, when entering into a treaty, intend to avoid creating opportunities for non-taxation or reduced taxation through tax evasion or avoidance, including through treaty shopping arrangements (this recommendation is included in Section B of the report).

- Second, it is recommended to include in tax treaties a specific antiabuse rule based on the limitation-on-benefits provisions included in treaties concluded by the United States and a few other countries (the "LOB rule"). Such a specific rule will address a large number of treaty shopping situations based on the legal nature, ownership in, and general activities of, residents of a Contracting State.

- Third, in order to address other forms of treaty abuse, including treaty shopping situations that would not be covered by the LOB rule described above (such as certain conduit financing arrangements), it is recommended to add to tax treaties a more general anti-abuse rule based on the principal purposes of transactions or arrangements (the principal purposes test or "PPT" rule).

The combination of the LOB and the PPT rules proposed in the report recognises that each rule has strengths and weaknesses and may not be appropriate for all countries. Also, these rules may require adaptations (e.g. to take account of constitutional or EU law restrictions). As already noted, as long as the approach that countries adopt effectively addresses treaty abuses along the lines of the report, some flexibility is allowed in implementing the report's recommendations. At a minimum, however, countries should agree to include in their tax treaties an express statement that their common intention is to eliminate double taxation without creating opportunities for non-taxation or reduced taxation through tax evasion or avoidance, including through treaty shopping arrangements; they should also implement that common intention through either the combined approach described above, the inclusion of the PPT rule or the LOB rule supplemented by a mechanism (such as a restricted PPT rule applicable to conduit financing arrangements or domestic anti-abuse rules or judicial doctrines that would achieve a similar result) that would deal with conduit arrangements not already dealt with in tax treaties. 
The LOB rule included in the report restricts the general scope of the treaty rule according to which a treaty applies to persons who are residents of a Contracting State. Paragraph 1 of the LOB rule provides that a resident of a Contracting State shall not be entitled to the benefits of the Convention unless it constitutes a "qualified person" under paragraph 2 or unless benefits are granted under the provisions of paragraphs 3, 4 or 5. Paragraph 2 determines who constitutes a "qualified person" by reference to the nature or attributes of various categories of persons; any person to which that paragraph applies is entitled to all the benefits of the Convention. Under paragraph 3, a person is entitled to the benefits of the Convention with respect to an item of income even if it does not constitute a "qualified person" under paragraph 2 as long as that item of income is derived in connection with the active conduct of a trade or business in that person's State of residence (subject to certain exceptions). Paragraph 4 is a "derivative benefits" provision that allows certain entities owned by residents of other States to obtain treaty benefits that these residents would have obtained if they had invested directly. Paragraph 5 allows the competent authority of a Contracting State to grant treaty benefits where the other provisions of the LOB rule would otherwise deny these benefits. Paragraph 6 includes a number of definitions that apply for the purposes of the Article. A detailed Commentary explains the various provisions of the LOB rule.

The PPT rule included in the report incorporates principles already recognised in the Commentary on Article 1 of the Model Tax Convention. It provides a more general way to address treaty abuse cases, including treaty shopping situations that would not be covered by the LOB rule (such as certain conduit financing arrangements). That rule reads as follows:

Notwithstanding the other provisions of this Convention, a benefit under this Convention shall not be granted in respect of an item of income or capital if it is reasonable to conclude, having regard to all relevant facts and circumstances, that obtaining that benefit was one of the principal purposes of any arrangement or transaction that resulted directly or indirectly in that benefit, unless it is established that granting that benefit in these circumstances would be in accordance with the object and purpose of the relevant provisions of this Convention.

That rule is accompanied by a Commentary and examples that explain and illustrate its application. 
The report includes additional recommendations for new specific treaty anti-abuse rules that seek to address strategies, other than treaty shopping, aimed at satisfying treaty requirements with a view to obtain inappropriately the benefit of certain provisions of tax treaties. These targeted rules, which are supplemented by the PPT rule described above, address (1) certain dividend transfer transactions; (2) transactions that circumvent the application of the treaty rule that allows source taxation of shares of companies that derive their value primarily from immovable property; (3) situations where an entity is resident of two Contracting States, and (4) situations where the State of residence exempts the income of permanent establishments situated in third States and where shares, debt-claims, rights or property are transferred to permanent establishments set up in countries that do not tax such income or offer preferential treatment to that income.

\section{Cases where a person tries to abuse the provisions of domestic tax law using treaty benefits}

The last part of Section A deals with situations where a person tries to abuse the provisions of domestic tax law using treaty benefits. The report recognises that the adoption of anti-abuse rules in tax treaties is not sufficient to address tax avoidance strategies that seek to circumvent provisions of domestic tax laws; these must be addressed through domestic anti-abuse rules, including through rules that may result from the work on other aspects of the Action Plan. Work aimed at preventing the granting of treaty benefits with respect to these strategies seeks to ensure that treaties do not inadvertently prevent the application of such domestic anti-abuse rules: granting the benefits of treaty provisions in such cases would be inappropriate to the extent that the result would be the avoidance of domestic tax.

The report refers to the parts of the Commentary of the OECD Model Tax Convention that already deal with this issue. It indicates that further work may be needed to take account of recommendations for the design of new domestic rules that may result from the work on various Action items, in particular Action 2 (Neutralise the effects of hybrid mismatch arrangements), Action 3 (Strengthen CFC rules), Action 4 (Limit base erosion via interest deductions and other financial payments) and Actions 8, 9 and 10 dealing with Transfer Pricing.

The report adds that the recommendation to include a PPT rule in treaties, which will incorporate the principle already included in paragraph 9.5 of the Commentary on Article 1 of the OECD Model Tax Convention, will provide a clear statement that the Contracting States intend to deny the 
application of the provisions of their treaties when transactions or arrangements are entered into in order to obtain the benefits of these provisions in inappropriate circumstances. The report recommends the inclusion of additional guidance in the Commentary included in the OECD Model Tax Convention in order to clarify that the incorporation of that principle into tax treaties will not affect the existing conclusions concerning the interaction between treaties and domestic anti-abuse rules.

The report also addresses two specific issues related to the interaction between treaties and specific domestic anti-abuse rules. The first issue relates to the application of tax treaties to restrict a Contracting State's right to tax its own residents. The report recommends that the principle that treaties do not restrict a State's right to tax its own residents (subject to certain exceptions) should be expressly recognized through the addition of a new treaty provision based on the so-called "saving clause" already found in United States tax treaties. The second issue deals with so-called "departure" or "exit" taxes, under which liability to tax on some types of income that has accrued for the benefit of a resident (whether an individual or a legal person) is triggered in the event that the resident ceases to be a resident of that State. The report recommends changes to the Commentary included in the Model Tax Convention in order to clarify that treaties do not prevent the application of these taxes.

\section{B. Clarification that tax treaties are not intended to be used to generate double non-taxation}

Section B of the report addresses the second part of Action 6, which required that work be done in order to "clarify that tax treaties are not intended to be used to generate double non-taxation". This clarification is provided through a reformulation of the title and preamble of the Model Tax Convention that will clearly state that the joint intention of the parties to a tax treaty is to eliminate double taxation without creating opportunities for tax evasion and avoidance. Given the particular concerns arising from treaty shopping arrangements, such arrangements are expressly mentioned as one example of tax avoidance that should not result from tax treaties. Under applicable rules of international public law, this clear statement of the intention of the signatories to a tax treaty will be relevant for the interpretation and application of the provisions of that treaty. 


\section{Tax policy considerations that, in general, countries should consider before deciding to enter into a tax treaty with another country}

Section $\mathrm{C}$ of the report addresses the third part of the work mandated by Action 6, which was "to identify the tax policy considerations that, in general, countries should consider before deciding to enter into a tax treaty with another country". The policy considerations that are described in Section C should help countries explain their decisions not to enter into tax treaties with certain low or no-tax jurisdictions; these policy considerations will also be relevant for countries that need to consider whether they should modify (or, ultimately, terminate) a treaty previously concluded in the event that a change of circumstances (such as changes to the domestic law of a treaty partner) raises BEPS concerns related to that treaty. It is recognised, however, that there are many non-tax factors that can lead to the conclusion, amendment or termination of a tax treaty and that each country has a sovereign right to decide whether it should do so. 



\section{Introduction}

1. At the request of the G20, the OECD published its Action Plan on Base Erosion and Profit Shifting (BEPS Action Plan) ${ }^{1}$ in July 2013. The BEPS Action Plan includes 15 actions to address BEPS in a comprehensive manner and sets deadlines to implement these actions.

2. The BEPS Action Plan identifies treaty abuse, and in particular treaty shopping, as one of the most important sources of BEPS concerns. Action 6 (Prevent Treaty Abuse) describes the work to be undertaken in this area. The relevant part of the Action Plan reads as follows:

Existing domestic and international tax rules should be modified in order to more closely align the allocation of income with the economic activity that generates that income:

Treaty abuse is one of the most important sources of BEPS concerns. The Commentary on Article 1 of the OECD Model Tax Convention already includes a number of examples of provisions that could be used to address treaty-shopping situations as well as other cases of treaty abuse, which may give rise to double non-taxation. Tight treaty antiabuse clauses coupled with the exercise of taxing rights under domestic laws will contribute to restore source taxation in a number of cases.

\section{Action 6 - Prevent treaty abuse}

Develop model treaty provisions and recommendations regarding the design of domestic rules to prevent the granting of treaty benefits in inappropriate circumstances. Work will also be done to clarify that tax treaties are not intended to be used to generate double non-taxation and to identify the tax policy considerations that, in general, countries should consider before deciding to enter into a tax treaty with another country. The work will be co-ordinated with the work on hybrids. 
3. This report is the result of the work carried on in the three different areas identified by Action 6:

A. Develop model treaty provisions and recommendations regarding the design of domestic rules to prevent the granting of treaty benefits in inappropriate circumstances.

B. Clarify that tax treaties are not intended to be used to generate double non-taxation.

C. Identify the tax policy considerations that, in general, countries should consider before deciding to enter into a tax treaty with another country.

4. The conclusions of the work in these three different areas of work correspond respectively to Sections A, B and C of this report. These conclusions take the form of changes to the OECD Model Tax Convention (in this report, all changes that are proposed to the existing text of the Model Tax Convention appear in bold italics for additions and strikethrough for deletions).

5. These changes reflect the agreement that the OECD Model should be amended to include the minimum level of protection against treaty abuse, including treaty shopping, described in the Executive summary and paragraph 14 below, as this minimum level of protection is necessary to effectively address BEPS. Whilst there is agreement that such changes should be made to the OECD Model, it is recognised that further work will be needed with respect to the precise contents of the model provisions and related Commentary included in Section A of this report, in particular the LOB rule. Further work is also needed with respect to the implementation of the minimum standard and with respect to the policy considerations relevant to treaty entitlement of collective investment vehicles (CIVs) and non-CIV funds. The model provisions and related Commentary included in Section A of this report should therefore be considered as drafts that are subject to improvement before their final version is released in September 2015. Some of the changes to be made will be necessary to take account of the results of other parts of the BEPS Action Plan. This is consistent with the holistic approach of the BEPS Action Plan. For example, one assumption in the drafting of the limitation-on-benefits rule found in Section A.1 below is that Action 5 (Counter harmful tax practices more effectively, taking into account transparency and substance) and Action 8 (Intangibles) will address BEPS concerns that may arise from a derivative benefits provision; that provision, or alternative means of addressing those BEPS concerns, may therefore need to be reviewed based on the outcome of the work on these Action items. Also, Section A.2, which addresses the relationship between domestic anti-abuse rules and tax treaty provisions, will need to take account 
of recommendations for the design of new domestic rules that may result from the work on various Action items, in particular Action 2 (Neutralise the effects of hybrid mismatch arrangements), Action 3 (Strengthen CFC rules), Action 4 (Limit base erosion via interest deductions and other financial payments) and Actions 8, 9 and 10 dealing with Transfer Pricing.

6. When examining the model treaty provisions included in this report, it is also important to note that these are model provisions that need to be adapted to the specificities of individual States and the circumstances of the negotiation of bilateral conventions. For example:

- Some countries may have constitutional or EU law restrictions that prevent them from adopting the exact wording of the model provisions that are recommended in this report.

- Some countries may have domestic anti-abuse rules that effectively prevent some of the treaty abuses described in this report and, to the extent that these rules conform with the principles set out in this report (and, in particular, in Section A.2) and offer the minimum protection referred to in paragraph 14 below, may not need some of the rules proposed in this report.

- Similarly, the courts of some countries have developed various interpretative tools (e.g. economic substance, substance-over-form) that effectively address various forms of domestic law and treaty abuses and these countries might not require the general treatyabuse provision included in subsection A.1(a)(ii) below or might prefer a more restricted form of that provision (see, for instance, paragraph 15 of the proposed Commentary in paragraph 17 below).

- The administrative capacity of some countries might prevent them from applying certain detailed treaty rules and might require them to opt for more general anti-abuse provisions.

For these reasons, a number of the model provisions included in this report offer alternatives and a certain degree of flexibility. There is agreement, however, that these alternatives aim to reach a common goal, i.e. to ensure that States incorporate in their treaties sufficient safeguards to prevent treaty abuse, in particular as regards treaty shopping. For that reason, the report recommends a minimum level of protection that should be implemented (see paragraph 14 below). 


\section{A. Treaty provisions and/or domestic rules to prevent the granting of treaty benefits in inappropriate circumstances}

7. In order to determine the best way to prevent the granting of treaty benefits in inappropriate circumstances, it was found useful to distinguish two types of cases: ${ }^{2}$

1. Cases where a person tries to circumvent limitations provided by the treaty itself.

2. Cases where a person tries to circumvent the provisions of domestic tax law using treaty benefits.

8. Since the first category of cases involve situations where a person seeks to circumvent rules that are specific to tax treaties, it is unlikely that these cases will be addressed by specific anti-abuse rules found in domestic law. Although a domestic general anti-abuse rule could prevent the granting of treaty benefits in these cases, a more direct approach involves the drafting of anti-abuse rules to be included in treaties. The situation is different in the second category of cases: since these cases involve the avoidance of domestic law, they cannot be addressed exclusively through treaty provisions and require domestic anti-abuse rules, which raises the issue of the interaction between tax treaties and these domestic rules.

\section{Cases where a person tries to circumvent limitations provided by the treaty itself}

a) Treaty shopping

9. The first requirement that must be met by a person who seeks to obtain benefits under a tax treaty is that the person must be "a resident of a Contracting State", as defined in Article 4 of the OECD Model Tax Convention. There are a number of arrangements through which a person who is not a resident of a Contracting State may attempt to obtain benefits that a tax treaty grants to a resident of that State. These arrangements are generally referred to as "treaty shopping". Treaty shopping cases typically involve persons who are residents of third States attempting to access indirectly the benefits of a treaty between two Contracting States. ${ }^{3}$

10. The OECD has previously examined the issue of treaty shopping in different contexts:

- The concept of "beneficial owner" was introduced in the Model Tax Convention in 1977 in order to deal with simple treaty shopping situations where income is paid to an intermediary 
resident of a treaty country who is not treated as the owner of that income for tax purposes (such as an agent or nominee). At the same time, a short new section on "Improper Use of the Convention" (which included two examples of treaty shopping) was added to the Commentary on Article 1 and the Committee indicated that it intended "to make an in-depth study of such problems and of other ways of dealing with them".

- That in-depth study resulted in the 1986 reports on Double Taxation and the Use of Base companies and Double Taxation and the Use of Conduit Companies, ${ }^{4}$ the issue of treaty shopping being primarily dealt with in the latter report.

- In 1992, as a result of the report on Double Taxation and the Use of Conduit Companies, various examples of provisions dealing with different aspects of treaty shopping were added to the section on "Improper Use of the Convention" in the Commentary on Article 1. These included the alternative provisions currently found in paragraphs 13 to 19 of the Commentary on Article 1 under the heading "Conduit company cases".

- In 2003, as a result of the report Restricting the Entitlement to Treaty Benefits ${ }^{5}$ (which was prepared as a follow-up to the 1998 Report Harmful Tax Competition: an Emerging Global Issue), ${ }^{6}$ new paragraphs intended to clarify the meaning of "beneficial owner" in some conduit situations were added to the Commentary on Articles 10, 11 and 12 and the section on "Improper Use of the Convention" was substantially extended to include additional examples of anti-abuse rules, including a comprehensive limitation-on-benefits provision based on the provision found in the $1996 \mathrm{US} \mathrm{Model}^{7}$ as well as a purpose-based anti-abuse provision based on UK practice and applicable to Articles 10,11, 12 and $21 .^{8}$

- Finally, additional work on the clarification of the "beneficial owner" concept, which resulted in changes to the Commentary on Articles 10, 11 and 12 that were included in the Model Tax Convention through the 2014 Update, has allowed the OECD to examine the limits of using that concept as a tool to address various treaty-shopping situations. As indicated in paragraph 12.5 of the Commentary on Article 10, "[w]hilst the concept of "beneficial owner' deals with some forms of tax avoidance (i.e. those involving the interposition of a recipient who is obliged to pass on the dividend to someone else), it does not deal with other cases of treaty shopping and must not, therefore, be considered as restricting 
in any way the application of other approaches to addressing such cases."

11. A review of the treaty practices of OECD and non-OECD countries shows that countries use different approaches to try to address treaty shopping cases not already dealt with by the provisions of the Model Tax Convention. Based on the advantages and limitations of these approaches, it is recommended that the following three-pronged approach be used to address treaty shopping situations:

- First, it is recommended to include in the title and preamble of tax treaties a clear statement that the Contracting States, when entering into a treaty, wish to prevent tax avoidance and, in particular, intend to avoid creating opportunities for treaty shopping (this recommendation is included in Section B of this report).

- Second, it is recommended to include in tax treaties a specific antiabuse rule based on the limitation-on-benefits provisions included in treaties concluded by the United States and a few other countries (the "LOB rule"). Such a specific rule will address a large number of treaty shopping situations based on the legal nature, ownership in, and general activities of, residents of a Contracting State (this recommendation is included in subsection A.1(a)(i) below).

- Third, in order to address other forms of treaty abuse, including treaty shopping situations that would not be covered by the LOB rule described in the preceding bullet point (such as certain conduit financing arrangements), it is recommended to add to tax treaties a more general anti-abuse rule based on the principal purposes of transactions or arrangements (the principal purposes test or "PPT" rule). That rule will incorporate into tax treaties the principles already reflected in paragraphs 9.5, 22, 22.1 and 22.2 of the Commentary on Article 1, according to which the benefits of a tax treaty should not be available where one of the principal purposes of arrangements or transactions is to secure a benefit under a tax treaty and obtaining that benefit in these circumstances would be contrary to the object and purpose of the relevant provisions of the tax treaty (this recommendation is included in subsection A.1(a)(ii) below).

12. The combination of the LOB and the PPT rules described above recognises that each rule has strengths and weaknesses. For instance, the various provisions of the LOB rule are based on objective criteria that provide more certainty than the PPT rule, which requires a case-by-case analysis based on what can reasonably be considered to be one of the 
principal purposes of transactions or arrangements. For that reason, the LOB rule is useful as a specific anti-abuse rule aimed at treaty shopping situations that can be identified on the basis of criteria based on the legal nature, ownership in, and general activities of, certain entities. The LOB rule, however, only focusses on treaty shopping and does not address other forms of treaty abuses; it also does not address certain forms of treaty shopping, such as conduit financing arrangements, through which a resident of Contracting State that would otherwise qualify for treaty benefits is used as an intermediary by persons who are not entitled to these benefits.

13. The combination of an LOB rule and a PPT rule may not be appropriate for all countries. For instance, as mentioned in paragraph 6 above, some countries may have domestic anti-abuse rules, or the courts of some countries may have developed various interpretative tools (e.g. economic substance or substance-over-form), that effectively address various forms of domestic law and treaty abuses and these countries might not require the general treaty anti-abuse provision included in subsection A.1(a)(ii) below or might prefer a more restricted form of that provision. It is also recognised that the $\mathrm{LOB}$ rule will need to be adapted to reflect certain of the factors referred to in paragraph 6 above (e.g. constitutional or EU law restrictions) as well as some policy choices concerning other aspects of a bilateral tax treaty between two Contracting States (e.g. the treatment of collective investment vehicles).

14. As long as the approach that countries adopt effectively addresses treaty abuses along the lines of this report, some flexibility is therefore possible. At a minimum, however, countries should agree to include in their tax treaties an express statement that their common intention is to eliminate double taxation without creating opportunities for non-taxation or reduced taxation through tax evasion or avoidance, including through treaty shopping arrangements (see Section B); they should also implement that common intention through either the combined approach described in paragraph 11 (subject to the necessary adaptations referred to in paragraph 6 above), the inclusion of the PPT rule or the inclusion of the LOB rule supplemented by a mechanism (such as the alternative provision included in paragraph 15 of the Commentary on the PPT rule that appears in subsection A.1(a)(ii) below or domestic anti-abuse rules or judicial doctrines that would achieve a similar result) that would deal with conduit arrangements not already dealt with in tax treaties.

15. Other recommendations included in this report will also assist in preventing treaty shopping. For instance, the proposals for specific treaty anti-abuse rules included in subsection A.1(b) will deal with some specific forms of treaty shopping, such as strategies aimed at using a permanent 
establishment located in a low-tax jurisdiction in order to take advantage of the exemption method applicable by a Contracting State. Section C, which includes tax policy considerations that, in general, States should consider before deciding to enter into a tax treaty with another country, may also contribute to the reduction of treaty shopping opportunities. Conversely, the approach recommended in paragraph 11 above is not restricted to treaty shopping cases and will also contribute to preventing the granting of treaty benefits in other inappropriate circumstances, this being particularly the case of the general treaty anti-abuse provision referred to at the end of that paragraph.

\section{i) Limitation-on-benefits rule}

16. The following specific anti-abuse rule aimed at treaty shopping, the LOB rule, is based on provisions already found in a number of tax treaties, including primarily treaties concluded by the United States but also some treaties concluded by Japan and India. The detailed Commentary that follows the LOB rule explains various aspects of the rule and, in some cases, indicates possible variations. Since this report focusses on the main features of the LOB rule, a number of technical issues, including issues on which the results of other parts of the BEPS Action Plan may have an impact, remain to be addressed. As indicated in paragraph 5, further work will be needed with respect to these issues.

\section{ARTICLE X}

\section{ENTITLEMENT TO BENEFITS}

1. Except as otherwise provided in this Article, a resident of a Contracting State shall not be entitled to a benefit that would otherwise be accorded by this Convention (other than a benefit under paragraph 3 of Article 4, paragraph 2 of Article 9 or Article 25), unless such resident is a "qualified person", as defined in paragraph 2, at the time that the benefit would be accorded.

2. A resident of a Contracting State shall be a qualified person at a time when a benefit would otherwise be accorded by the Convention if, at that time, the resident is:

a) an individual;

b) a Contracting State, or a political subdivision or local authority thereof, or a person that is wholly-owned by such State, political subdivision or local authority;

c) a company or other entity, if, throughout the taxable period that includes that time 
i) the principal class of its shares (and any disproportionate class of shares) is regularly traded on one or more recognised stock exchanges, and either:

A) its principal class of shares is primarily traded on one or more recognised stock exchanges located in the Contracting State of which the company or entity is a resident; or

B) the company's or entity's primary place of management and control is in the Contracting State of which it is a resident; or

ii) at least 50 per cent of the aggregate voting power and value of the shares (and at least 50 per cent of any disproportionate class of shares) in the company or entity is owned directly or indirectly by five or fewer companies or entities entitled to benefits under subdivision i) of this subparagraph, Iprovided that, in the case of indirect ownership, each intermediate owner is a resident of either Contracting State];

d) a person, other than an individual, that

i) is a /list of the relevant non-profit organisations found in each Contracting State],

ii) was constituted and is operated exclusively to administer or provide pension or other similar benefits, provided that more than 50 per cent of the beneficial interests in that person are owned by individuals resident in either Contracting State, or

iii) was constituted and is operated to invest funds for the benefit of persons referred to in subdivision ii), provided that substantially all the income of that person is derived from investments made for the benefit of these persons;

e) a person other than an individual, if

i) on at least half the days of the taxable period that includes that time, persons who are residents of that Contracting State and that are entitled to the benefits of this Convention under subparagraph a), b) or d), or subdivision i) of subparagraph c), of this paragraph own, directly or indirectly, shares representing at least 50 per cent of the aggregate voting power and value 
(and at least 50 per cent of any disproportionate class of shares) of the person, [provided that, in the case of indirect ownership, each intermediate owner is a resident of that Contracting State], and

ii) less than 50 per cent of the person's gross income, as determined in the person's Contracting State of residence, for the taxable period that includes that time is paid or accrued, directly or indirectly, to persons who are not residents of either Contracting State entitled to the benefits of this Convention under subparagraph a), b) or d), or subdivision i) of subparagraph c), of this paragraph in the form of payments that are deductible for purposes of the taxes covered by this Convention in the person's Contracting State of residence (but not including arm's length payments in the ordinary course of business for services or tangible property);

f) [possible provision on collective investment vehicles] $]^{1}$

[Footnote 1:] This subparagraph should be drafted (or omitted) based on how collective investment vehicles are treated in the Convention and are used and treated in each Contracting State: see the Commentary on the subparagraph and paragraphs 6.4 to 6.38 of the Commentary on Article 1.]

3. a) A resident of a Contracting State will be entitled to benefits of this Convention with respect to an item of income derived from the other Contracting State, regardless of whether the resident is a qualified person, if the resident is engaged in the active conduct of a business in the firstmentioned Contracting State (other than the business of making or managing investments for the resident's own account, unless these activities are banking, insurance or securities activities carried on by a bank or [list financial institutions similar to banks that the Contracting States agree to treat as such], insurance enterprise or registered securities dealer respectively), and the income derived from the other Contracting State is derived in connection with, or is incidental to, that business.

b) If a resident of a Contracting State derives an item of income from a business activity conducted by that resident in the other Contracting State, or derives an item of income arising in the other Contracting State from an 
associated enterprise, the conditions described in subparagraph a) shall be considered to be satisfied with respect to such item only if the business activity carried on by the resident in the first-mentioned Contracting State is substantial in relation to the business activity carried on by the resident or associated enterprise in the other Contracting State. Whether a business activity is substantial for the purposes of this paragraph will be determined based on all the facts and circumstances.

c) For purposes of applying this paragraph, activities conducted by persons connected to a person shall be deemed to be conducted by such person. A person shall be connected to another if one possesses at least 50 per cent of the beneficial interest in the other (or, in the case of a company, at least 50 per cent of the aggregate vote and value of the company's shares or of the beneficial equity interest in the company) or another person possesses at least 50 per cent of the beneficial interest (or, in the case of a company, at least 50 per cent of the aggregate voting power and value of the company's shares or of the beneficial equity interest in the company) in each person. In any case, a person shall be considered to be connected to another if, based on all the relevant facts and circumstances, one has control of the other or both are under the control of the same person or persons.

[4. A company that is a resident of a Contracting State shall also be entitled to a benefit that would otherwise be accorded by this Convention if, at the time when that benefit would be accorded:

a) at least 95 per cent of the aggregate voting power and value of its shares (and at least 50 per cent of any disproportionate class of shares) is owned, directly or indirectly, by seven or fewer persons that are equivalent beneficiaries, provided that in the case of indirect ownership, each intermediate owner is itself an equivalent beneficiary, and

b) less than 50 per cent of the company's gross income, as determined in the company's State of residence, for the taxable period that includes that time, is paid or accrued, directly or indirectly, to persons who are not equivalent beneficiaries, in the form of payments (but not including arm's length payments in the ordinary course of business 
for services or tangible property) that are deductible for the purposes of the taxes covered by this Convention in the company's State of residence.]

5. If a resident of a Contracting State is not entitled, under the preceding provisions of this Article, to all benefits provided under this Convention, the competent authority of the Contracting State that would otherwise have granted benefits to which that resident is not entitled shall nevertheless treat that resident as being entitled to these benefits, or benefits with respect to a specific item of income or capital, if such competent authority, upon request from that resident and after consideration of the relevant facts and circumstances, determines that the establishment, acquisition or maintenance of the resident and the conduct of its operations did not have as one of its principal purposes the obtaining of benefits under this Convention. The competent authority of the Contracting State to which the request has been made will consult with the competent authority of the other State before rejecting a request made under this paragraph by a resident of that other State.

6. For purposes of the preceding provisions of this Article:

a) the term "recognised stock exchange" means:

i) [list of stock exchanges agreed to at the time of signature]; and

ii) any other stock exchange agreed upon by the competent authorities of the Contracting States;

b) the term "principal class of shares" means the ordinary or common shares of the company, provided that such class of shares represents the majority of the voting power and value of the company. If no single class of ordinary or common shares represents the majority of the aggregate voting power and value of the company, the "principal class of shares" are those classes that in the aggregate represent a majority of the aggregate voting power and value of the company. In the case of a company participating in a dual listed company arrangement, the principal class of shares will be determined after excluding the special voting shares which were issued as a means of establishing that dual listed company arrangement;

c) the term "disproportionate class of shares" means any class of shares of a company resident in one of the Contracting States that entitles the shareholder to 
disproportionately higher participation, through dividends, redemption payments or otherwise, in the earnings generated in the other Contracting State by particular assets or activities of the company;

d) a company's "primary place of management and control" will be in the Contracting State of which it is a resident only if executive officers and senior management employees exercise day-to-day responsibility for more of the strategic, financial and operational policy decision making for the company (including its direct and indirect subsidiaries) in that Contracting State than in any other State and the staff of such persons conduct more of the day-to-day activities necessary for preparing and making those decisions in that Contracting State than in any other State;

e) [possible definition of "collective investment vehicle"]; ${ }^{1}$

[Footnote 1: A definition of the term "collective investment vehicle" should be added if a provision on collective investment vehicles is included in paragraph 2 (see subparagraph $2 \mathrm{f}$ )).];

If) the term "equivalent beneficiary" means a resident of any other State, but only if that resident

i) A) would be entitled to all the benefits of a comprehensive convention for the avoidance of double taxation between that other State and the State from which the benefits of this Convention are claimed under provisions analogous to subparagraph a), b) or d), or subdivision i) of subparagraph c), of paragraph 2 of this Article, provided that if such convention does not contain a comprehensive limitation on benefits article, the person would be entitled to the benefits of this Convention by reason of subparagraph a), b) or d), or subdivision i) of subparagraph c), of paragraph 2 of this Article if such person were a resident of one of the Contracting States under Article 4 of this Convention; and

B) with respect to income referred to in Articles 10, 11 and 12 of this Convention, would be entitled under such convention to a rate of tax with respect to the 
particular class of income for which benefits are being claimed under this Convention that is at least as low as the rate applicable under this Convention; or

ii) is a resident of a Contracting State that is entitled to the benefits of this Convention by reason of subparagraph a), b), subdivision i) of subparagraph c) or subparagraph d) of paragraph 2 of this Article;]

g) the term "dual listed company arrangement" means an arrangement pursuant to which two publicly listed companies, while maintaining their separate legal entity status, shareholdings and listings, align their strategic directions and the economic interests of their respective shareholders through:

i) the appointment of common (or almost identical) boards of directors, except where relevant regulatory requirements prevent this;

ii) management of the operations of the two companies on a unified basis;

iii) equalised distributions to shareholders in accordance with an equalisation ratio applying between the two companies, including in the event of a winding up of one or both of the companies;

iv) the shareholders of both companies voting in effect as a single decision-making body on substantial issues affecting their combined interests; and

v) cross-guarantees as to, or similar financial support for, each other's material obligations or operations except where the effect of the relevant regulatory requirements prevents such guarantees or financial support; and

h) with respect to entities that are not companies, the term "shares" means interests that are comparable to shares.

\section{Commentary on the $\mathrm{LOB}$ rule}

Preliminary remarks

1. This Article contains provisions that are intended to prevent various forms of treaty shopping through which persons who are not residents of a Contracting State might establish an entity that would be 
a resident of that State in order to reduce or eliminate taxation in the other Contracting State through the benefits of the tax treaty concluded between these two States. Allowing persons who are not directly entitled to treaty benefits (such as the reduction or elimination of withholding taxes on dividends, interest or royalties) to obtain these benefits indirectly through treaty shopping would frustrate the bilateral and reciprocal nature of tax treaties. If, for instance, a State knows that its residents can indirectly access the benefits of treaties concluded by another State, it may have little interest in granting reciprocal benefits to residents of that other State through the conclusion of a tax treaty. Also, in such a case, the benefits that would be indirectly obtained may not be appropriate given the nature of the tax system of the former State; if, for instance, that State does not levy an income tax on a certain type of income, it would be inappropriate for its residents to benefit from the provisions of a tax treaty concluded between two other States that grant a reduction or elimination of source taxation for that type of income and that were designed on the assumption that the two Contracting States would tax such income.

2. The provisions of the Article seek to deny treaty benefits in the case of structures that typically result in the indirect granting of treaty benefits to persons that are not directly entitled to these benefits whilst recognising that in some cases, persons who are not residents of a Contracting State may establish an entity in that State for legitimate business reasons. Although these provisions apply regardless of whether or not a particular structure was adopted for treaty-shopping purposes, the Article allows the competent authority of a Contracting State to grant treaty benefits where the other provisions of the Article would otherwise deny these benefits but the competent authority determines that the structure did not have as one of its principal purposes the obtaining of benefits under the Convention.

3. The Article restricts the general scope of Article 1, according to which the Convention applies to persons who are residents of a Contracting State. Paragraph 1 of the Article provides that a resident of a Contracting State shall not be entitled to the benefits of the Convention unless it constitutes a "qualified person" under paragraph 2 or unless benefits are granted under the provisions of paragraphs 3, 4 or 5. Paragraph 2 determines who constitutes a "qualified person" by reference to the nature or attributes of various categories of persons; any person to which that paragraph applies is entitled to all the benefits of the Convention. Under paragraph 3, a person is entitled to the benefits of the Convention with respect to an item of income even if it does not constitute a "qualified person" under paragraph 2 as long as 
that item of income is derived in connection with the active conduct of a trade or business in that person's State of residence (subject to certain exceptions). Paragraph 4 is a "derivative benefits" rule that allows certain entities owned by residents of third States to obtain treaty benefits provided that these residents would have been entitled to equivalent benefits if they had invested directly. Paragraph 5 includes the provisions that allow the competent authority of a Contracting State to grant treaty benefits where the other provisions of the Article would otherwise deny these benefits. Paragraph 6 includes a number of definitions that apply for the purposes of the Article.

\section{Paragraph 1}

1. Except as otherwise provided in this Article, a resident of a Contracting State shall not be entitled to a benefit that would otherwise be accorded by this Convention (other than a benefit under paragraph 3 of Article 4, paragraph 2 of Article 9 or Article 25), unless such resident is a "qualified person", as defined in paragraph 2, at the time that the benefit would be accorded.

4. Paragraph 1 provides that a resident of a Contracting State, as defined under Article 4, will be entitled to the benefits otherwise accorded to residents of a Contracting State under the Convention only if it constitutes a "qualified person" under paragraph 2 or unless benefits are otherwise granted under paragraphs 3, 4 or 5. The benefits otherwise accorded to a resident of a Contracting State under the Convention include all limitations to the Contracting States' taxing rights under Articles 6 through 21, the elimination of double taxation provided by Article 23 and the protection afforded to residents of a Contracting State under Article 24. The Article does not, however, restrict the availability of treaty benefits under paragraph 3 of Article 4, paragraph 2 of Article 9 or Article 25 or under the few provisions of the Convention that do not require that a person be a resident of Contracting State in order to enjoy the benefits of those provisions (e.g. the provisions of paragraph 1 of Article 24, to the extent that they apply to nationals who are not residents of either Contracting State).

5. Paragraph 1 does not extend in any way the scope of the benefits granted by the Convention. Thus, a resident of a Contracting State who constitutes a "qualified person" under paragraph 2 must still meet the conditions of the other provisions of the Convention in order to obtain these benefits (e.g. that resident must be the beneficial owner of dividends in order to benefit from the provisions of paragraph 2 of Article 10) and these benefits may be denied or restricted under applicable anti-abuse rules. 
6. Paragraph 1 applies at any time when the Convention would otherwise provide a benefit to a resident of a Contracting State. Thus, for example, it applies at the time when income to which Article 6 applies is derived by a resident of a Contracting State, at the time that dividends to which Article 10 applies are paid to a resident of a Contracting State or at any time when profits to which Article 7 applies are made. The paragraph requires that, in order to be entitled to the benefit provided by the relevant provision of the Convention, the resident of the Contracting State must be a "qualified person", within the meaning of paragraph 2, at the relevant time. In some cases, however, the definition of "qualified person" requires that a resident of a Contracting State must satisfy certain conditions over a period of time in order to constitute a "qualified person" at a given time.

\section{Paragraph 2}

2. A resident of a Contracting State shall be a qualified person at a time when a benefit would otherwise be accorded by the Convention if, at that time, the resident is:

7. Paragraph 2 has six subparagraphs, each of which describes a category of residents that are qualified persons.

8. It is intended that the provisions of paragraph 2 will be selfexecuting. Unlike the provisions of paragraph 5, discussed below, claiming benefits under paragraph 2 does not require advance competent authority ruling or approval. The tax authorities may, of course, on review, determine that the taxpayer has improperly interpreted the paragraph and is not entitled to the benefits claimed.

\section{Individuals - subparagraph 2 a)}

a) an individual;

9. Subparagraph 2 a) provides that any individual who is a resident of a Contracting State will be a qualified person. As explained in paragraph 35 below, under some treaty provisions, a collective investment vehicle must be treated as an individual for the purposes of applying the relevant treaty; where that is the case, such a collective investment vehicle will therefore constitute a qualified person by virtue of subparagraph a). 
Governments - subparagraph 2 b)

b) a Contracting State, or a political subdivision or local authority thereof, or a person that is wholly-owned by such State, political subdivision or local authority;

10. Subparagraph 2 b) provides that the Contracting States and any political subdivision or local authority thereof constitute qualified persons. The subparagraph applies to any part of a State, such as an agency or instrumentality that does not constitute a separate person. The last part of the subparagraph provides that a separate legal person which constitutes a resident of a Contracting State and is wholly-owned by a Contracting State, or a political subdivision or local authority thereof, will also be a qualified person and, therefore, will be entitled to all the benefits of the Convention whilst it qualifies as such. The wording of the subparagraph may need to be adapted to reflect the different legal nature that State-owned entities, such as sovereign wealth funds, may have in the Contracting States as well as the different views that these States may have concerning the application of Article 4 to these entities (see paragraphs 6.35 to 6.39 of the Commentary on Article 1 and paragraphs 8.5 to 8.7 of the Commentary on Article 4).

Publicly-traded companies and entities -subparagraph 2 c)

c) a company or other entity, if, throughout the taxable period that includes that time

i) the principal class of its shares (and any disproportionate class of shares) is regularly traded on one or more recognised stock exchanges, and either:

A) its principal class of shares is primarily traded on one or more recognised stock exchanges located in the Contracting State of which the company or entity is a resident; or

B) the company's or entity's primary place of management and control is in the Contracting State of which it is a resident; or

ii) at least 50 per cent of the aggregate voting power and value of the shares (and at least 50 per cent of any disproportionate class of shares) in the company or entity is owned directly or indirectly by five or fewer companies or entities entitled to benefits under subdivision i) of this subparagraph, Iprovided that, in 
the case of indirect ownership, each intermediate owner is a resident of either Contracting Statel;

11. Subparagraph c) recognises that, as a general rule, because the shares of publicly-traded companies and of some entities are generally widely-held, these companies and entities are unlikely to be established for treaty shopping. The provisions of subdivision i) apply to publiclytraded companies and entities and the provisions of subdivision ii) apply to subsidiaries of publicly-traded companies and entities. As indicated in subparagraph $h$ ) of paragraph 6, for the purposes of subparagraph c), the term "shares" covers comparable interests in entities, other than companies, to which the subparagraph applies; this includes, for example, publicly-traded units of a trust.

12. Subdivision i) provides that a company or entity resident in a Contracting State constitutes a qualified person at a time when a benefit is provided by the Convention if, throughout the taxable period that includes that time, the principal class of its shares, and any disproportionate class of shares, is regularly traded on one or more recognised stock exchanges, provided that the company or entity also satisfies at least one of the following additional requirements: first, the company's or entity's principal class of shares is primarily traded on one or more recognised stock exchanges located in the Contracting State of which the company or entity is a resident or, second, the company's or entity's primary place of management and control is in its State of residence. These additional requirements take account of the fact that whilst a publicly-traded company or entity may be technically resident in a given State, it may not have a sufficient relationship with that State to justify allowing such a company or entity to obtain the benefits of treaties concluded by that State. Such a sufficient relationship may be established by the fact that the shares of the publicly-traded company or entity are primarily traded in recognised stock exchanges situated in the State of residence of the company or entity; given the fact that the globalisation of financial markets means that shares of publicly-listed companies that are residents of some States are often traded on foreign stock exchanges, the alternative test provides that this sufficient relationship may also be established by the fact that the company or entity is primarily managed and controlled in its State of residence.

13. A company or entity whose principal class of shares is regularly traded on a recognised stock exchange will nevertheless not qualify for benefits under subparagraph c) of paragraph 2 if it has a disproportionate class of shares that is not regularly traded on a recognised stock exchange. 
14. The terms "recognised stock exchange", "principal class of shares" and "disproportionate class of shares" are defined in paragraph 6 (see below). As indicated in these definitions, the principal class of shares of a company must be determined after excluding special voting shares which are issued as a means of establishing a "dual listed company arrangement", which is also defined in paragraph 6.

15. The regular trading requirement can be met by trading of issued shares on any recognised exchange or exchanges located in either State. Trading on one or more recognised stock exchanges may be aggregated for purposes of this requirement; a company or entity could therefore satisfy this requirement if its shares are regularly traded, in whole or in part, on a recognised stock exchange located in the other Contracting State.

16. Subdivision (i)A) includes the additional requirement that the shares of the company or entity be primarily traded in one or more recognised stock exchanges located in the State of residence of the company or entity. In general, the principal class of shares of a company or entity are "primarily traded" on one or more recognised stock exchanges located in the State of residence of that company or entity if, during the relevant taxation year, the number of shares in the company's or entity's principal class of shares that are traded on these stock exchanges exceeds the number of shares in the company's or entity's principal class of shares that are traded on established securities markets in any other State. Some States, however, consider that the fact that shares of a company or entity resident in a Contracting State are primarily traded on recognised stock exchanges situated in States that are part of regional grouping (e.g. in a State that is part of the European Economic Area within which rules relating to stock exchanges and securities create a single market for securities trading) constitutes a sufficient safeguard against the use of that company or entity for treaty-shopping purposes; States that share that view may modify subdivision (i)A) accordingly.

17. Subdivision (i)B) provides the alternative requirement applicable to a company or entity whose principal class of shares is regularly traded on recognised stock exchanges but not primarily traded on recognised stock exchanges situated in the State of residence of the company or entity. Such a company or entity may claim treaty benefits if its "primary place of management and control" (as defined in subparagraph d) of paragraph 6) is in its State of residence.

18. The conditions of subparagraph c) must be satisfied throughout the taxable period of the company or entity. This does not require that 
the shares of the company or entity be traded on the relevant stock exchanges each day of the relevant period. For shares to be considered as regularly traded on one or more stock exchanges throughout the taxable period, it is necessary that more than a very small percentage of the shares be actively traded during a sufficiently large number of days included in that period. The test would be met, for example, if 10 per cent of the average number of outstanding shares of a given class of shares of a company were traded during 60 days of trading taking place in the taxable period of the company. The phrase "taxable period" in subparagraphs c) and e) refers to the period for which an annual tax return must be filed in the State of residence of the company or entity. If the Contracting States have a concept corresponding to "taxable period" in their domestic law, such as "taxable year", they are free to replace the reference to taxable period by that other concept.

19. A company resident in a Contracting State is entitled to all the benefits of the Convention under subdivision ii) of subparagraph c) of paragraph 2 if five or fewer publicly-traded companies described in subdivision i) are the direct or indirect owners of at least 50 per cent of the aggregate vote and value of the company's shares (and at least 50 per cent of any disproportionate class of shares). If the publicly-traded companies are indirect owners, however, each of the intermediate companies must be a resident of one of the Contracting States. Some States, however, consider that this last requirement is unduly restrictive and prefer to omit it.

20. Thus, for example, a company that is a resident of a Contracting State, all the shares of which are owned by another company that is a resident of the same State, would qualify for benefits under the Convention if the principal class of shares (and any disproportionate classes of shares) of the parent company are regularly and primarily traded on a recognised stock exchange in that Contracting State. Such a subsidiary would not qualify for benefits under subdivision ii), however, if the publicly-traded parent company were a resident of a third State, for example, and not a resident of one of the Contracting States. Furthermore, if a parent company in one of the Contracting States indirectly owned the bottom-tier company through a chain of subsidiaries, each such subsidiary in the chain, as an intermediate owner, must be a resident of either Contracting State in order for the subsidiary to meet the test in subdivision ii). As explained in the previous paragraph, however, some States consider that, in the case of publicly-listed companies, the condition that each subsidiary in the chain must be a resident of either Contracting State is not necessary in 
order to prevent treaty shopping; these States therefore prefer to omit that additional condition.

Charitable organisations and pension funds -subparagraph 2 d)

d) a person, other than an individual, that

i) is a /list of the relevant non-profit organisations found in each Contracting Statel,

ii) was constituted and is operated exclusively to administer or provide pension or other similar benefits, provided that more than 50 per cent of the beneficial interests in that person are owned by individuals resident in either Contracting State, or

iii) was constituted and is operated to invest funds for the benefit of persons referred to in subdivision ii), provided that substantially all the income of that person is derived from investments made for the benefit of these persons;

21. Subparagraph 2 d) provides rules under which certain non-profit organisations and pension funds that qualify as resident of a Contracting State (see paragraphs 8.6 and 8.7 of the Commentary on Article 4) will be entitled to all the benefits of the Convention.

22. Entities listed in subdivision i) automatically qualify for treaty benefits without regard to the residence of their beneficiaries or members. These entities would generally correspond to those that are exempt from tax in their State of residence and that are constituted and operated exclusively to fulfil certain social functions (e.g. charitable, scientific, artistic, cultural, or educational).

23. Under subdivision ii), a resident pension fund will qualify for treaty benefits if more than 50 per cent of the beneficial interests in that person are owned by individuals resident of either Contracting State. For purposes of this provision, the term "beneficial interests in that person" should be understood to refer to the interests held by persons entitled to receive pension benefits from the fund. Some States, however, may wish to relax the 50 per cent beneficial interest requirement in subdivision ii) (e.g. where a State is part of a regional grouping of States, such as the European Union, which permits pension funds to be constituted in any State which is a member of that regional grouping).

24. Subdivision iii) constitutes an extension of the rule of subdivision ii) applicable to pension funds. It applies to so-called "funds of funds", 
which are funds which do not directly provide pension benefits to residents of either Contracting State but are constituted and operated to invest funds of pension funds that are themselves pension funds qualifying for benefits under subdivision ii). Subdivision iii) only applies, however, if substantially all the income of such a "fund of funds" is derived from investments made for the benefit of pension funds qualifying for benefits under subdivision ii).

\section{Ownership / Base Erosion - subparagraph 2 e)}

e) a person other than an individual, if

i) on at least half the days of the taxable period, persons who are residents of that Contracting State and that are entitled to the benefits of this Convention under subparagraph a), b) or d), or subdivision i) of subparagraph c), of this paragraph own, directly or indirectly, shares representing at least 50 per cent of the aggregate voting power and value (and at least 50 per cent of any disproportionate class of shares) of the person, Iprovided that, in the case of indirect ownership, each intermediate owner is a resident of that Contracting State/, and

ii) less than 50 per cent of the person's gross income for the taxable period, as determined in the person's Contracting State of residence, is paid or accrued, directlv or indirectlv, to persons who are not residents of either Contracting State entitled to the benefits of this Convention under subparagraph a), b) or d), or subdivision i) of subparagraph $c$ ), of this paragraph in the form of payments that are deductible for purposes of the taxes covered by this Convention in the person's Contracting State of residence (but not including arm's length payments in the ordinary course of business for services or tangible property);

25. Subparagraph 2 e) provides an additional method to qualify for treaty benefits that applies to any form of legal entity that is a resident of a Contracting State. The test provided in subparagraph e), the so-called ownership and base erosion test, is a two-part test; both parts must be satisfied for the resident to be entitled to treaty benefits under subparagraph $2 e$ ). 
26. Under subdivision i), which is the ownership part of the test, 50 per cent or more of each class of shares in the person must be owned, directly or indirectly, on at least half the days of the person's taxable period, by persons who are residents of the Contracting State of which that person is a resident and that are themselves entitled to treaty benefits under subparagraphs a), b) or d), or subdivision i) of subparagraph c). In the case of indirect owners, however, each of the intermediate owners must be a resident of that Contracting State. Some States, however, consider that this last requirement is unduly restrictive and prefer to omit it.

27. Whilst subdivision i) will typically be relevant in the case of private companies, it may also apply to an entity such as a trust that is a resident of a Contracting State and that otherwise satisfies the requirements of this subdivision. According to subparagraph $h$ ) of paragraph 6, the reference to "shares", in the case of entities that are not companies, means interests that are comparable to shares; this would generally be the case of the beneficial interests in a trust. For the purposes of subdivision i), the beneficial interests in a trust will be considered to be owned by its beneficiaries in proportion to each beneficiary's actuarial interest in the trust. The interest of a beneficiary entitled to the remaining part of a trust will be equal to 100 per cent less the aggregate percentages held by income beneficiaries. A beneficiary's interest in a trust will not be considered to be owned by a person entitled to benefits under the other provisions of paragraph 2 if it is not possible to determine the beneficiary's actuarial interest. Consequently, if it is not possible to determine the actuarial interest of the beneficiaries in a trust, the ownership test under subdivision i) cannot be satisfied, unless all possible beneficiaries are persons entitled to benefits under the other subparagraphs of paragraph 2.

28. Subdivision ii), which constitutes the base erosion part of the test, is satisfied with respect to a person if less than 50 per cent of the person's gross income for the taxable period, as determined under the tax law in the person's State of residence, is paid or accrued to persons who are not residents of either Contracting State entitled to benefits under subparagraphs a), b) or d), or subdivision i) of subparagraph c), in the form of payments deductible for tax purposes in the payer's State of residence.

29. For the purposes of the test in subdivision ii), deductible (i.e. base-eroding) payments do not include arm's-length payments in the ordinary course of business for services or tangible property. To the extent they are deductible from the taxable base under the tax law in the person's State of residence, trust distributions constitute such base- 
eroding payments. Depreciation and amortisation deductions, which do not represent payments or accruals to other persons, are not taken into account for the purposes of subdivision ii). Income that is subjected to full taxation in the State of source should not be considered to be a base-eroding payment even if it is deductible by the payer. For example, the payment of a "group contribution" that may be made by a company that is a resident of a Contracting State to the permanent establishment, situated in the same State, of a non-resident company that is part of the same group should not be taken into account as such a payment would be taxable in the same State where it would be deducted.

30. The ownership and base erosion tests included in subparagraph e) require a determination for each taxable period of the entity; when these tests are met for a given taxable period, the entity constitutes a qualified person at any time within that taxable period. The taxable period to which subparagraph e) refers is determined by the taxation law of the State of residence of the entity.

Collective investment vehicles - subparagraph 2 f)

f)_[possible provision on collective investment vehicles] ${ }^{1}$

[Footnote 1] This subparagraph should be drafted (or omitted) based on how collective investment vehicles are treated in the Convention and are used and treated in each Contracting State: see the Commentary on the subparagraph and paragraphs 6.4 to 6.38 of the Commentary on Article 1.

31. As indicated in the footnote to subparagraph $f$ ), whether a specific rule concerning collective investment vehicles (CIVs) should be included in paragraph 2, and, if so, how that rule should be drafted, will depend on how the Convention applies to CIVs and on the treatment and use of CIVs in each Contracting State. Such a specific rule will frequently be needed since a CIV may not be a qualified person under either the other provisions of paragraph 2 or 3, because, in many cases

- the interests in the CIV are not publicly-traded (even though these interests are widely distributed);

- these interests are held by residents of third States;

- the distributions made by the CIV are deductible payments, and

- the CIV is used for investment purposes rather than for the "active conduct of a business" within the meaning of paragraph 3. 
32. Paragraphs 6.8 to 6.34 of the Commentary on Article 1 discuss various factors that should be considered for the purpose of determining the treaty entitlement of CIVs and these paragraphs are therefore relevant when determining whether a provision on CIVs should be included in paragraph 2 and how it should be drafted. These paragraphs include alternative provisions that may be used to deal adequately with the CIVs that are found in each Contracting State. As explained below, the use of these provisions may make it unnecessary to include a specific rule on CIVs in paragraph 2, although it will be important to make sure that, in such a case, the definition of "equivalent beneficiary", if the term is used for the purposes of one of these alternative provisions, is adapted to reflect the definition included in paragraph 6.

33. If it is included, subparagraph f) will address cases where a Contracting State agrees that CIVs established in the other Contracting State constitute residents of that other State under the analysis in paragraphs 6.9 to 6.12 of the Commentary on Article 1 (such agreement may be evidenced by a mutual agreement as envisaged in paragraph 6.16 of the Commentary on Article 1 or may result from judicial or administrative pronouncements). The provisions of the Article, including subparagraph f), are not relevant with respect to a $C I V$ that does not qualify as a resident of a Contracting State under the analysis in paragraphs 6.9 to 6.12 of the Commentary on Article 1. Also, the provisions of subparagraph f) are not relevant where the treaty entitlement of a CIV is dealt with under a treaty provision similar to one of the alternative provisions in paragraphs $6.17,6.21,6.26,6.27$ and 6.32 of the Commentary on Article 1.

34. As explained in paragraphs 6.19 and 6.20 of the Commentary on Article 1, Contracting States wishing to address the issue of CIVs' entitlement to treaty benefits may want to consider the economic characteristics, including the potential for treaty shopping, of the different types of CIVs that are used in each Contracting State.

35. As a result of that analysis, they may conclude that the tax treatment of CIVs established in the two States does not give rise to treaty-shopping concerns and decide to include in their bilateral treaty the alternative provision in paragraph 6.17 of the Commentary on Article 1, which would expressly provide for the treaty entitlement of CIVs established in each State and, at the same time, would ensure that they constitute qualified persons under subparagraph a) of paragraph 2 of the Article (because a CIV to which that alternative provision would apply would be treated as an individual). In such a case, subparagraph f) should be omitted. States that share the view that CIVs established in 
the two States do not give rise to treaty shopping concerns but that do not include in their treaty the alternative provision in paragraph 6.17 of the Commentary on Article 1 should ensure that any CIV that is a resident of a Contracting State should constitute a qualified person. In that case, subparagraph f) should be drafted as follows:

f) a CIV Ia definition of CIV would be included in subparagraph f) of paragraph 6];

36. The Contracting States could, however, conclude that CIVs present the opportunity for residents of third States to receive treaty benefits that would not have been available if these residents had invested directly and, for that reason, might prefer to draft subparagraph f) in a way that will ensure that a CIV that is a resident of a Contracting State will constitute a qualified person but only to the extent that the beneficial interests in the CIV are owned by equivalent beneficiaries. In that case, subparagraph f) should be drafted as follows:

f) a collective investment vehicle, but only to the extent that, at that time, the beneficial interests in the CIV are owned by residents of the Contracting State in which the collective investment vehicle is established or by equivalent beneficiaries.

37. That treatment corresponds to the treatment that would result from the inclusion in a tax treaty of a provision similar to the alternative provision in paragraph 6.21 of the Commentary on Article 1. As explained in paragraphs 6.18 to 6.24 of the Commentary on Article 1, the inclusion of such an alternative provision would provide a more comprehensive solution to treaty issues arising in connection with CIVs because it would address treaty-shopping concerns whilst, at the same time, clarifying the tax treaty treatment of CIVs in both Contracting States. If that alternative provision is included in a tax treaty, subparagraph f) would not be necessary as regards the CIVs to which that alternative provision would apply: since that alternative provision provides that a CIV to which it applies shall be treated as an individual (to the extent that the beneficial interests in that CIV are owned by equivalent beneficiaries), that $C I V$ will constitute a qualified person under subparagraph a) of paragraph 2 of the Article.

38. The approach described in the preceding two paragraphs, like the approach in paragraphs 6.21, 6.26 and 6.28 of the Commentary on Article 1, makes it necessary for the CIV to make a determination, when a benefit is claimed as regards a specific item of income, regarding the proportion of holders of interests who would have been entitled to 
benefits had they invested directly. As indicated in paragraph 6.29 of the Commentary on Article 1, however, the ownership of interests in CIVs changes regularly, and such interests frequently are held through intermediaries. For that reason, the CIV and its managers often do not themselves know the names and treaty status of the beneficial owners of interests. It would therefore be impractical for the CIV to collect such information from the relevant intermediaries each time the CIV receives income. Accordingly, Contracting States should be willing to accept practical and reliable approaches that do not require such daily tracing. As indicated in paragraph 6.31 of the Commentary on Article 1, the proportion of investors in the CIV is likely to change relatively slowly even though the identity of individual investors will change daily. For that reason, the determination of the extent to which the beneficial interests in a CIV are owned by equivalent beneficiaries should be made at regular intervals, the determination made at a given time being applicable to payments received until the following determination. This corresponds to the approach described in paragraph 6.31 of the Commentary on Article 1, according to which:

... it would be a reasonable approach to require the CIV to collect from other intermediaries, on specified dates, information enabling the CIV to determine the proportion of investors that are treaty-entitled. This information could be required at the end of a calendar or fiscal year or, if market conditions suggest that turnover in ownership is high, it could be required more frequently, although no more often than the end of each calendar quarter. The CIV could then make a claim on the basis of an average of those amounts over an agreed-upon time period. In adopting such procedures, care would have to be taken in choosing the measurement dates to ensure that the CIV would have enough time to update the information that it provides to other payers so that the correct amount is withheld at the beginning of each relevant period.

39. Another view that Contracting States may adopt regarding CIVs is that expressed in paragraph 6.26 of the Commentary on Article 1. Contracting States that adopt that view may wish to draft subparagraph f) so that a CIV that is a resident of a Contracting State would only constitute a qualified person to the extent that the beneficial interests in that CIV are owned by residents of the Contracting State in which the CIV is established. In that case, subparagraph f) should be drafted as follows:

f) a collective investment vehicle, but only to the extent that, at that time, the beneficial interests in the collective 
investment vehicle are owned by residents of the Contracting State in which the collective investment vehicle is established.

Since the inclusion of the alternative provision in paragraph 6.26 of the Commentary on Article 1 would achieve the same result with respect to the CIVs to which it would apply, subparagraph f) would not be necessary, if that alternative provision is included in a treaty, as regards the CIVs to which that provision would apply.

40. A variation on the preceding approach would be to consider that a CIV that is a resident of a Contracting State should constitute a qualified person if the majority of the beneficial interests in that CIV are owned by individuals who are residents of the Contracting State in which the CIV is established. This result could be achieved by omitting subparagraph $f$ ) and simply relying on the application of subparagraph 2) e) (the so-called ownership and base erosion test).

41. Another possible view that the Contracting States could adopt would be to conclude that the fact that a substantial proportion of the CIV's investors are treaty-eligible is adequate protection against treaty shopping, and thus that it is appropriate to provide an ownership threshold above which benefits would be provided with respect to all income received by a CIV. An alternative provision that would ensure that result is included in paragraph 6.27 of the Commentary on Article 1 and subparagraph f) would not be necessary, if the Contracting States include that provision in their bilateral treaty, with respect to the CIVs to which the provision would apply. If that provision is not included in the treaty, the scope of subparagraph f) could be broadened in order to achieve a similar result by referring to "a collective investment vehicle, but only if I I per cent of the beneficial interests in the collective investment vehicle are owned by residents of the Contracting State in which the collective investment vehicle is established and equivalent beneficiaries".

42. Similarly, the Contracting States may use the alternative provision in paragraph 6.32 of the Commentary on Article 1 where they consider "that a publicly-traded collective investment vehicle cannot be used effectively for treaty shopping because the shareholders or unit holders of such a collective investment vehicle cannot individually exercise control over it". In such case, subparagraph f) would not be necessary with respect to the CIVs to which the alternative provision would apply. States that share that view but that have not included the alternative provision in their treaty could draft subparagraph f) to read: 
f) a collective investment vehicle if the principal class of shares in the collective investment vehicle is listed and regularly traded on a recognised stock exchange.

43. Finally, as explained in paragraph 6.25 of the Commentary on Article 1, States that share the concern described in that paragraph about the potential deferral of taxation that could arise with respect to a CIV that is subject to no or low taxation and that may accumulate its income rather than distributing it on a current basis may wish to negotiate provisions that extend benefits only to those CIVs that are required to distribute earnings currently. Depending on their drafting, such provisions may render subparagraph f) unnecessary.

Paragraph 3 - Active conduct of a business

3. a) A resident of a Contracting State will be entitled to benefits of this Convention with respect to an item of income derived from the other Contracting State, regardless of whether the resident is a qualified person, if the resident is engaged in the active conduct of a business in the first-mentioned Contracting State (other than the business of making or managing investments for the resident's own account, unless these activities are banking, insurance or securities activities carried on by a bank or /list financial institutions similar to banks that the Contracting States agree to treat as suchl, insurance enterprise or registered securities dealer respectively), and the income derived from the other Contracting State is derived in connection with, or is incidental to, that business.

b) If a resident of a Contracting State derives an item of income from a business activity conducted by that resident in the other Contracting State, or derives an item of income arising in the other Contracting State from an associated enterprise, the conditions described in subparagraph a) shall be considered to be satisfied with respect to such item only if the business activity carried on by the resident in the first-mentioned Contracting State is substantial in relation to the business activity carried on by the resident or associated enterprise in the other Contracting State. Whether a business activity is substantial for the purposes of this paragraph will be determined based on all the facts and circumstances.

c) For purposes of applying this paragraph, activities conducted by persons connected to a person shall be deemed to be conducted by such person. A person shall be connected to another if one 
possesses at least 50 per cent of the beneficial interest in the other (or, in the case of a company, at least 50 per cent of the aggregate vote and value of the company's shares or of the beneficial equity interest in the company) or another person possesses at least 50 per cent of the beneficial interest (or, in the case of a company, at least 50 per cent of the aggregate voting power and value of the company's shares or of the beneficial equity interest in the company) in each person. In any case, a person shall be considered to be connected to another if, based on all the relevant facts and circumstances, one has control of the other or both are under the control of the same person or persons.

44. Paragraph 3 sets forth an alternative test under which a resident of a Contracting State may receive treaty benefits with respect to certain items of income that are connected to an active business conducted in its State of residence. This paragraph recognises that where an entity resident of a Contracting State actively carries on business activities in that State, including activities conducted by connected persons, and derives income from the other Contracting State in connection with, or incidental to, such business activities, granting treaty benefits with respect to such income does not give rise to treaty-shopping concerns regardless of the nature and ownership of the entity. The paragraph will provide treaty benefits in a large number of situations where benefits would otherwise be denied under paragraph 1 because the entity is not a “qualified person" under paragraph 2.

45. A resident of a Contracting State may qualify for benefits under paragraph 3 whether or not it also qualifies under paragraph 2. Under the active-conduct test of paragraph 3, a person (typically a company) will be eligible for treaty benefits if it satisfies two conditions: (1) it is engaged in the active conduct of a business in its State of residence; and (2) the payment for which benefits are sought is related to the business. In certain cases, an additional requirement that the business be substantial in size relative to the activity in the source State generating the income must be met.

46. Subparagraph a) sets forth the general rule that a resident of a Contracting State engaged in the active conduct of a business in that State may obtain the benefits of the Convention with respect to an item of income derived from the other Contracting State. The item of income, however, must be derived in connection with, or be incidental to, that business. 
47. The term "business" is not defined and, under the general rule of paragraph 2 of Article 3, must therefore be given the meaning that it has under domestic law. An entity generally will be considered to be engaged in the active conduct of a business only if persons through whom the entity is acting (such as officers or employees of a company) conduct substantial managerial and operational activities.

48. The business of making or managing investments for the resident's own account will be considered to be a business only when the relevant activities are part of banking, insurance or securities activities conducted by a bank or financial institution that the Contracting States would consider to be similar to a bank (such as a credit union or building society), an insurance enterprise or a registered securities dealer respectively. Such activities conducted by a person other than a bank (or financial institution agreed to by the Contracting States), insurance enterprise or registered securities dealer will not be considered to be the active conduct of a business, nor would they be considered to be the active conduct of a business if conducted by a bank (or financial institution agreed to by the Contracting States), insurance enterprise or registered securities dealer but not as part of the enterprise's banking, insurance or dealer business. Since a headquarters operation is in the business of managing investments, a company that functions solely as a headquarters company will not be considered to be engaged in the active conduct of a business for purposes of paragraph 3.

49. An item of income is derived in connection with a business if the income-producing activity in the State of source is a line of business that "forms a part of" or is "complementary to" the business conducted in the State of residence by the income recipient.

50. A business activity generally will be considered to form part of a business activity conducted in the State of source if the two activities involve the design, manufacture or sale of the same products or type of products, or the provision of similar services. The line of business in the State of residence may be upstream, downstream, or parallel to the activity conducted in the State of source. Thus, the line of business may provide inputs for a manufacturing process that occurs in the State of source, may sell the output of that manufacturing process, or simply may sell the same sorts of products that are being sold by the business carried on in the State of source. The following examples illustrate these principles:

Example 1: ACO is a company resident of State $A$ and is engaged in an active manufacturing business in that State. ACO owns 100 
per cent of the shares of $B C O$, a company resident of State $B . B C O$ distributes ACO's products in State B. Since the business activities conducted by the two companies involve the same products, BCO's distribution business is considered to form a part of ACO's manufacturing business.

Example 2: The facts are the same as in Example 1, except that ACO does not manufacture products. Rather, ACO operates a large research and development facility in State $A$ that licenses intellectual property to affiliates worldwide, including BCO. BCO and other affiliates then manufacture and market the ACOdesigned products in their respective markets. Since the activities conducted by ACO and BCO involve the same product lines, these activities are considered to form a part of the same business.

51. For two activities to be considered to be "complementary," the activities need not relate to the same types of products or services, but they should be part of the same overall industry and be related in the sense that the success or failure of one activity will tend to result in success or failure for the other. Where more than one business is conducted in the State of source and only one of the businesses forms a part of or is complementary to a business conducted in the State of residence, it is necessary to identify the business to which an item of income is attributable. Royalties generally will be considered to be derived in connection with the business to which the underlying intangible property is attributable. Dividends will be deemed to be derived first out of profits of the treaty-benefited business, and then out of other profits. Interest income may be allocated under any reasonable method consistently applied.

Example 3. CCO is a company resident of State C that operates an international airline. DCO is a wholly-owned subsidiary of CCO resident of State D. DCO operates a chain of hotels in State D that are located near airports served by flights operated by CCO. CCO frequently sells tour packages that include air travel to State $D$ and lodging at DCO's hotels. Although both companies are engaged in the active conduct of a business, the businesses of operating a chain of hotels and operating an airline are distinct businesses. Therefore DCO's business does not form a part of CCO's business. DCO's business, however, is considered to be complementary to CCO's business because these two businesses are part of the same overall industry (travel) and the links between these activities tend to make them interdependent. 
Example 4. The facts are the same as in Example 3, except that DCO owns an office building in the other Contracting State instead of a hotel chain. No part of CCO's business is conducted through the office building. DCO's business is not considered to form a part of or to be complementary to CCO's business. They are engaged in distinct businesses in separate industries, and there is no economic dependence between the two operations.

Example 5. ECO is a company resident of State E. ECO produces and sells flowers in State $E$ and other countries. ECO owns all the shares of FCO, a company resident of State F. FCO is a holding company that is not engaged in a business. FCO owns all the shares of three companies that are resident of State F: GCO, HCO and ICO. GCO distributes ECO's flowers under the ECO trademark in State F. HCO markets a line of lawn care products in State $F$ under the ECO trademark. In addition to being sold under the same trademark, GCO's and HCO's products are sold in the same stores and sales of each company's products tend to generate increased sales of the other's products. ICO imports fish from State $E$ and distributes it to fish wholesalers in State F. For purposes of paragraph 3, the business of GCO forms a part of the business of $\mathrm{ECO}$, the business of $\mathrm{HCO}$ is complementary to the business of $E C O$, and the business of ICO is neither part of nor complementary to that of ECO.

Example 6. JCO is a company resident of State J. JCO produces and sells baby food in State J and other countries. JCO acquires all the shares of $\mathrm{KCO}$, a company resident of State $\mathrm{K}$ that produces and distributes jam and similar food products. JCO and KCO are both involved in the food industry, the products resulting from the businesses activities carried on by these companies are sold in the same stores and sales of each company's products would be affected by any incident related to the quality of any of their products. For purposes of paragraph 3, the business of $\mathrm{KCO}$ is complementary to the business of JCO.

52. An item of income derived from the State of source is "incidental to" the business carried on in the State of residence if production of the item facilitates the conduct of the business in the State of residence. An example of incidental income is income derived from the temporary investment of working capital of a resident of one Contracting State.

53. Subparagraph b) of paragraph 3 states a further condition to the general rule in subparagraph a) in cases where the business generating the item of income in question is carried on either by the person 
deriving the income or by any associated enterprises. Subparagraph b) states that the business carried on in the State of residence, under these circumstances, must be substantial in relation to the activity in the State of source. The substantiality requirement is intended to prevent a narrow case of treaty-shopping abuses in which a company attempts to qualify for benefits by engaging in de minimis connected business activities in the treaty State of which it is resident (i.e. activities that have little economic cost or effect with respect to the company's business as a whole).

54. The determination of substantiality is made based upon all the facts and circumstances and takes into account the comparative sizes of the businesses in each Contracting State, the nature of the activities performed in each Contracting State, and the relative contributions made to that business in each Contracting State. In any case, in making each determination or comparison, due regard will be given to the relative sizes of the economies and the markets in the two Contracting States.

Example 7. LCO is a pharmaceutical company resident of State L. LCO is engaged in an active manufacturing business in State $L$ and also conducts research and development in State $L$. All the shares of $L C O$ are owned by $O C O$, a company resident of State $O$. LCO has developed different anti-malaria drugs which are produced, under LCO's patents and trademarks, by MCO, a subsidiary of LCO which is a resident of State M. LCO sells these drugs, along with the other drugs that it manufactures, in State $L$ and other States where malaria is almost non-existent. MCO pays a royalty to $L C O$ for the use of the IP. Taking into account the nature of the business activities performed in State L and State M and the relative contribution made to the trade or business in each state, the royalty payment is entitled to treaty benefits. Due regard is also given to the relative small size of the market of anti-malaria drugs in State L (where the drugs are primarily sold to people who travel to parts of the world where malaria is widespread) compared to the market for such products in State M. Given the nature of the market for the drug in each country as well as all the other facts and circumstances, the business activity carried on by LCO in State $L$ may be considered substantial in relation to the business activity carried on by MCO in State M.

Example 8: PCO, a company resident of State $P$, a developing country, has developed a line of luxury cosmetics that incorporate ingredients from plants that are primarily found in State P. PCO is the owner of patents, trade names and trademarks for these 
cosmetics. PCO's shares are held in equal proportion by three shareholders: a company that is a resident of State P, another company that is a resident of State $Q$ and a third company that is a resident of State R. PCO harvests and conditions the plants in State P. The plants are then shipped to State $S$ (a large affluent country where there is an important demand for luxury cosmetics) where they are transformed into cosmetics by SCO, a subsidiary of $P C O$ that is a resident of State $S$. The cosmetics are distributed in State $S$ by another subsidiary, TCO, which is also a resident of State $S$, under trade names and trademarks licensed to TCO by $P C O$. The cosmetics are labelled "made in State S". Due to the relatively small size of the economy of State P compared to the size of the economy of State $S$, the business activity carried on by PCO in State $P$ is substantial in relation to the business activity carried on by SCO and TCO in State S.

55. The determination in subparagraph b) also is made separately for each item of income derived from the State of source. It is therefore possible that a person would be entitled to the benefits of the Convention with respect to one item of income but not with respect to another. If a resident of a Contracting State is entitled to treaty benefits with respect to a particular item of income under paragraph 3 , the resident is entitled to all benefits of the Convention insofar as they affect the taxation of that item of income in the State of source.

56. The application of the substantiality requirement only to income from associated enterprises focuses only on potential abuse cases, and does not hamper certain other kinds of non-abusive activities, even though the income recipient resident in a Contracting State may be very small in relation to the entity generating income in the other Contracting State. For example, if a small research firm in one State develops a process that it licenses to a very large, unrelated, pharmaceutical manufacturer in another State, the size of the research firm in the first State would not have to be tested against the size of the manufacturer. Similarly, a small bank of one State that makes a loan to a very large unrelated company operating a business in the other State would not have to pass a substantiality test to receive treaty benefits under paragraph 3.

57. Subparagraph c) of paragraph 3 provides special attribution rules for purposes of applying the substantive rules of subparagraphs a) and b). Thus, these rules apply for purposes of determining whether a person meets the requirements in subparagraph a) that it be engaged in the active conduct of a business and that the item of income is derived in connection with that active business, and for making the comparison 
required by the "substantiality" requirement in subparagraph b). Subparagraph c) attributes to a person activities conducted by persons "connected" to such person. A person (" $X$ ") is connected to another person (" $Y$ ") if $X$ possesses 50 per cent or more of the beneficial interest in $Y$ (or if $Y$ possesses 50 per cent or more of the beneficial interest in $X)$. For this purpose, $X$ is connected to a company if $X$ owns shares representing 50 per cent or more of the aggregate voting power and value of the company or 50 per cent or more of the beneficial equity interest in the company. $X$ also is connected to $Y$ if a third person possesses 50 per cent or more of the beneficial interest in both $X$ and $Y$. For this purpose, if $X$ or $Y$ is a company, the threshold relationship with respect to such company or companies is 50 per cent or more of the aggregate voting power and value or 50 per cent or more of the beneficial equity interest. Finally, $X$ is connected to $Y$ if, based upon all the facts and circumstances, $X$ controls $Y, Y$ controls $X$, or $X$ and $Y$ are controlled by the same person or persons.

Paragraph 4 -Derivative benefits

44. A company that is a resident of a Contracting State shall also be entitled to a benefit that would otherwise be accorded by this Convention if, at the time when that benefit would be accorded:

a) at least 95 per cent of the aggregate voting power and value of its shares (and at least 50 percent of any disproportionate class of shares) is owned, directly or indirectly, by seven or fewer persons that are equivalent beneficiaries, provided that in the case of indirect ownership, each intermediate owner is itself an equivalent beneficiary, and

b) less than 50 per cent of the company's gross income, as determined in the company's State of residence, for the taxable period that includes that time, is paid or accrued, directly or indirectly, to persons who are not equivalent beneficiaries, in the form of payments (but not including arm's length payments in the ordinary course of business for services or tangible property) that are deductible for the purposes of the taxes covered by this Convention in the company's State of residence. $I^{9}$

58. Paragraph 4 sets forth a derivative benefits test that is potentially applicable to all treaty benefits, although the test is applied to individual items of income. In general, this derivative benefits test entitles certain companies that are residents of a Contracting State to treaty benefits if the owner of the company would have been entitled to at least the same 
benefit had the income in question flowed directly to that owner. To qualify under this paragraph, the company must meet an ownership test and a base erosion test.

59. Subparagraph a) sets forth the ownership test. Under this test, seven or fewer equivalent beneficiaries must own shares representing at least 95 per cent of the aggregate voting power and value of the company and at least 50 per cent of any disproportionate class of shares. Ownership may be direct or indirect. The term "equivalent beneficiary" is defined in subparagraph f) of paragraph 6.

60. Subparagraph b) sets forth the base erosion test. A company meets this base erosion test if less than 50 percent of its gross income (as determined in the company's State of residence) for the taxable period that includes the time when the benefit would be accorded is paid or accrued, directly or indirectly, to a person or persons who are not equivalent beneficiaries in the form of payments deductible for tax purposes in the company's State of residence. These amounts do not include arm's length payments in the ordinary course of business for services or tangible property. This test is the same as the base erosion test in subparagraph e)(ii) of paragraph 2, except that the test in subparagraph b) focuses on base eroding payments to persons who are not equivalent beneficiaries.

61. Some States consider that the provisions of paragraph 4 create unacceptable risks of treaty shopping with respect to payments that are deductible in the State of source. These States prefer to restrict the scope of paragraph 4 to dividends, which are typically not deductible. States that share that view are free to amend the first part of the paragraph so that it reads as follows:

4. A company that is a resident of a Contracting State shall also be entitled to a benefit that would otherwise be accorded under Article 10 of this Convention if, at the time when that benefit would be accorded:

\section{Paragraph 5 - Discretionary relief}

5. If a resident of a Contracting State is not entitled, under the preceding provisions of this Article, to all benefits provided under this Convention, the competent authority of the Contracting State that would otherwise have granted benefits to which that resident is not entitled shall nevertheless treat that resident as being entitled to these benefits, or benefits with respect to a specific item of income or capital, if such competent authority, upon request from that 
resident and after consideration of the relevant facts and circumstances, determines that the establishment, acquisition or maintenance of the resident and the conduct of its operations did not have as one of its principal purposes the obtaining of benefits under this Convention. The competent authority of the Contracting State to which the request has been made will consult with the competent authority of the other State before rejecting a request made under this paragraph by a resident of that other State.

62. Paragraph 5 provides that where, under paragraphs 1 to 4 of the Article, a resident of one of the Contracting States is not entitled to all benefits of the Convention in a Contracting State, that resident may request the competent authority of that State to grant these benefits. In such a case, the competent authority will grant these benefits if, after considering the relevant facts and circumstances, it determines that neither the establishment, acquisition, or maintenance of the resident, nor the conduct of its operations, had as one of its principal purposes the obtaining of benefits under the Convention.

63. In order to be granted benefits under paragraph 5, the person must establish, to the satisfaction of the competent authority of the State from which benefits are being claimed, that there were clear reasons, unrelated to the obtaining of treaty benefits, for its formation, acquisition, or maintenance and that any reasons related to the obtaining of treaty benefits were clearly secondary to those unrelated reasons. Through this paragraph, a resident that is not entitled to the benefits of the Convention under paragraphs 1 through 4 but who has a sufficient relationship to its State of residence, taking into account considerations other than those addressed through the objective tests in paragraphs 1 through 4, may be able to obtain treaty benefits. Where a foreign company is engaged in a mobile business such as financing, or where the domestic law of a Contracting State provides a special tax treatment for certain activities conducted in special zones or offshore (e.g. licensing intangibles) those factors will not be evidence of a nontax business reason for locating in that State. In such cases, additional favourable business factors must be present to establish a sufficient relationship to that State. Paragraph 5 also provides that the competent authority of the State to which the request is made will consult with the competent authority of the other State before refusing to exercise its discretion to grant benefits to a resident of that other State.

64. Although a request under paragraph 5 will usually be made by a resident of a Contracting State to the competent authority of the other Contracting State, there may be cases in which a resident of a Contracting State may request the competent authority of its own State 
of residence to grant relief under paragraph 5 . This would be the case if the treaty benefits that are requested are provided by the State of residence, such as the benefits of the provisions of Articles $23 A$ and 23 $B$ concerning the elimination of double taxation. In such cases, the paragraph does not require the competent authority to consult the competent authority of the other State before denying the request.

65. The paragraph grants broad discretion to the competent authority. The paragraph does require, however, that the competent authority must consider the relevant facts and circumstances before reaching a decision and must consult the competent authority of the other Contracting State before rejecting a request to grant benefits. The first requirement seeks to ensure that the competent authority will consider each request on its own merits whilst the requirement that the competent authority of the other Contracting State be consulted should ensure that Contracting States treat similar cases in a consistent manner and can justify their decision on the basis of the facts and circumstances of the particular case. This consultation process does not, however, require that the competent authority to which the request has been presented obtain the agreement of the competent authority that is consulted. The determination that neither the establishment, acquisition or maintenance of the resident making the request, nor the conduct of its operations, had as one of its principal purposes the obtaining of benefits under the Convention is a matter that is left to the discretion of the competent authority to which the request is made. Once it has determined that this is the case, the competent authority is required to grant benefits but it may then grant all of the benefits of the Convention to the taxpayer making the request, or it may grant only certain benefits. For instance, it may grant benefits only with respect to a particular item of income in a manner similar to paragraph 3. Further, the competent authority may establish conditions, such as setting time limits on the duration of any relief granted.

66. The request for a determination under paragraph 5 may be presented before (e.g. through a ruling request) or after the establishment, acquisition or maintenance of the person for whom the request is made. Where the request is made after such establishment, acquisition or maintenance, any benefits granted by the competent authority may be allowed retroactively.

67. Whilst it is impossible to provide a detailed list of all the facts and circumstances that would be relevant to the determination referred to in paragraph 5, examples of such facts and circumstances include the history, structure, ownership and operations of the resident that makes the request, whether that resident is a long standing entity that was 
recently acquired by non-residents for non-tax reasons, whether the resident carries on substantial business activities, whether the resident's income for which the benefits are requested is subject to double taxation and whether the establishment or use of the resident gives rise to nontaxation or reduced taxation of the income.

68. To reduce the resource implications of having to consider requests for discretionary relief, and to discourage vexatious requests, Contracting States may find it useful to publish guidelines on the types of cases that it considers will and will not qualify for discretionary relief. However, any administrative conditions that a Contracting State imposes on applicants should not deter persons making requests where they consider that they have a reasonable prospect of satisfying a competent authority that benefits should be granted.

\section{Paragraph 6 -Definitions}

6. For purposes of the preceding provisions of this Article:

69. Paragraph 6 includes a number of definitions that apply for the purposes of the Article. These definitions supplement the definitions included in Articles 3, 4 and 5 of the Convention, which apply throughout the Convention.

The term "recognised stock exchange" - subparagraph a)

a) the term "recognised stock exchange" means:

i) Jlist of stock exchanges agreed to at the time of signaturel; and

ii) anv other stock exchange agreed upon by the competent authorities of the Contracting States;

70. The definition of "recognised stock exchange" first includes stock exchanges that both Contracting States agree to identify at the time of the signature of the Convention. Although this would typically include stock exchanges established in the Contracting States on which shares of publicly listed companies and entities that are residents of these States are actively traded, the stock exchanges to be identified in the definition need not be established in one of the Contracting States. This recognises that the globalisation of financial markets and the prominence of some large financial centres have resulted in the shares of many public companies being actively traded on more than one stock exchange and on stock exchanges situated outside the State of residence of these companies. 
71. The definition also allows the competent authorities of the Contracting States to supplement, through a subsequent agreement, the list of stock exchanges identified in the definition at the time of signature of the Convention.

The term "principal class of shares" - subparagraph b)

b) the term "principal class of shares" means the ordinary or common shares of the companv, provided that such class of shares represents the majority of the voting power and value of the company. If no single class of ordinary or common shares represents the majority of the aggregate voting power and value of the company, the "principal class of shares" are those classes that in the aggregate represent a majority of the aggregate voting power and value of the company. In the case of a company participating in a dual listed company arrangement, the principal class of shares will be determined after excluding the special voting shares which were issued as a means of establishing that dual listed company arrangement.

72. The definition of the term "principal class of shares" refers to the ordinary or common shares of a company but only if these shares represent the majority of the voting rights as well as of the value of the company. If a company has only one class of shares, it will naturally constitute its "principal class of shares". If a company has more than one class of shares, it is necessary to determine which class or classes constitute the "principal class of shares", which will be the class of shares, or any combination of classes of shares, that represent, in the aggregate, a majority of the voting power and value of the company. Although in a particular case involving a company with several classes of shares it is conceivable that more than one group of classes could be identified that would represent the majority of the voting power and value of the company, it is only necessary to identify one such group that meets the conditions of subparagraph c) of paragraph 2 in order for the company to be entitled to treaty benefits under that provision (benefits will not be denied to the company even if a second group of shares representing the majority of the voting power and value of the company, but not satisfying the conditions of subparagraph c) of paragraph 2, could be identified).

73. The last part of the definition provides an exception applicable to companies that participate in a dual listed company arrangement, as defined in paragraph g). In the case of these companies, special voting shares issued for the purposes of implementing that dual listed company 
arrangement must not be taken into account for the purposes of determining the principal class of shares of these companies.

The term "disproportionate class of shares" - subparagraph c)

c) the term "disproportionate class of shares" means anv class of shares of a company resident in one of the Contracting States that entitles the shareholder to disproportionately higher participation, through dividends, redemption payments or otherwise, in the earnings generated in the other Contracting State by particular assets or activities of the company;

74. Under the definition of the term "disproportionate class of shares", which is relevant for the purposes of paragraph 4 and subparagraphs c) and e) of paragraph 2, a company has a disproportionate class of shares if it has outstanding shares that are subject to terms or other arrangements that entitle the holder of these shares to a larger portion of the company's income derived from the other Contracting State than that to which the holder would be entitled in the absence of such terms or arrangements. Thus, for example, a company resident in one Contracting State has a "disproportionate class of shares" if some of the outstanding shares of that company are "tracking shares" that pay dividends based upon a formula that approximates the company's return on its assets employed in the other Contracting State. This is illustrated by the following example:

Example: ACO is a company resident of State A. ACO has issued common shares and preferred shares. The common shares are listed and regularly traded on the principal stock exchange of State $A$. The preferred shares have no voting rights and entitle their holders to receive dividends equal in amount to interest payments that ACO receives from unrelated borrowers in State $B$. The preferred shares are owned entirely by a single shareholder who is a resident of a third State with which State $B$ does not have a tax treaty. The common shares account for more than 50 per cent of the value of $A C O$ and for 100 per cent of the voting power. Since the owner of the preferred shares is entitled to receive payments corresponding to ACO's interest income arising in State $B$, the preferred shares constitute a "disproportionate class of shares" and because these shares are not regularly traded on a recognised stock exchange, ACO will not qualify for benefits under subparagraph c) of paragraph 2. 
The term "primary place of management and control" - subparagraph d)

d) a companv's "primary place of management and control" will be in the Contracting State of which it is a resident only if executive officers and senior management emplovees exercise dav-to-dav responsibility for more of the strategic, financial and operational policy decision making for the company (including its direct and indirect subsidiaries) in that Contracting State than in any other State and the staff of such persons conduct more of the day-to-day activities necessary for preparing and making those decisions in that Contracting State than in any other State;

75. The term "primary place of management and control" is relevant for the purposes of subparagraph c) of paragraph 2. This term must be distinguished from the concept of "place of effective management", which was used, before [date of the next update], in paragraph 3 of Article 4 and in various provisions, including Article 8, applicable to the operation of ships and aircraft. The concept of "place of effective management" was interpreted by some States as being ordinarily the place where the most senior person or group of persons (for example a board of directors) made the key management and commercial decisions necessary for the conduct of the company's business. The concept of the primary place of management and control, by contrast, refers to the place where the day-to-day responsibility for the management of the company (and its subsidiaries) is exercised. A company's primary place of management and control will be situated in the State of residence of that company only if the executive officers and senior management employees exercise day-to-day responsibility for more of the strategic, financial and operational policy decision making for the company (including direct and indirect subsidiaries) in that State than in the other State or any third State, and the staff that support the management in making those decisions are also based in that State. Thus, the test looks to the overall activities of the relevant persons to see where those activities are conducted. In most cases, it will be a necessary, but not a sufficient, condition that the headquarters of the company (that is, the place at which the chief executive officer and other top-level executives normally are based) be located in the Contracting State of which the company is a resident.

76. In order to determine a company's primary place of management and control, it is necessary to determine which persons are to be considered "executive officers and senior management employees". In some countries, it will not be necessary to look beyond the executives 
who are members of the board of directors (i.e. the so-called "inside directors"). That will not always be the case, however; in fact, the relevant persons may be employees of subsidiaries if those persons make the strategic, financial and operational policy decisions. Moreover, it would be necessary to take into account any special voting arrangements that result in certain persons making certain decisions without the participation of other persons.

The term "collective investment vehicle" - subparagraph e)

\section{e) Ipossible definition of "collective investment vehicle"l; ;}

[Footnote 1: A definition of the term "collective investment vehicle" should be added if a provision on collective investment vehicles is included in paragraph 2 (see subparagraph $2 \mathrm{f}$ )).];

77. As indicated in the footnote to subparagraph $e$ ), a definition of "collective investment vehicle" should be included if a provision dealing with collective investment vehicles is included in subparagraph f) of paragraph 2. That definition should identify the collective investment vehicles of each Contracting State to which that provision is applicable and could be drafted as follows:

the term "collective investment vehicle" means, in the case of [State A], a I I and, in the case of [State B], a I ], as well as any other investment fund, arrangement or entity established in either Contracting State which the competent authorities of the Contracting States agree to regard as a collective investment vehicle for purposes of this paragraph;

78. As explained in paragraph 6.22 of the Commentary on Article 1, it is intended that the open parts of that definition would include crossreferences to relevant tax or securities law provisions of each State that would identify the CIVs to which subparagraph f) of paragraph 2 should apply.

The term "equivalent beneficiary" - subparagraph f) ${ }^{1}$

Lf) the term "equivalent beneficiary" means a resident of any other State, but only if that resident

i) A) would be entitled to all the benefits of a comprehensive convention for the avoidance of double taxation between that other State and the State from which the benefits of this Convention are claimed under provisions analogous to 
subparagraph a), b) or d), or subdivision i) of subparagraph c), of paragraph 2 of this Article, provided that if such convention does not contain a comprehensive limitation on benefits article, the person would be entitled to the benefits of this Convention by reason of subparagraph a), b), $\begin{array}{lllll}\text { subdivision i) of subparagraph } & \text { c), } & \text { or }\end{array}$ subparagraph d) of paragraph 2 of this Article if such person were a resident of one of the Contracting States under Article 4 of this Convention; and

B) with respect to income referred to in Articles 10, 11 and 12 of this Convention, would be entitled under such convention to a rate of tax with respect to the particular class of income for which benefits are being claimed under this Convention that is at least as low as the rate applicable under this Convention; or

ii) is a resident of a Contracting State that is entitled to the benefits of this Convention by reason of subparagraph a), b) or d), or subdivision i) of subparagraph c), of paragraph 2 of this Article.l

[Footnote 1: The inclusion of a definition of "equivalent beneficiary" will depend on whether paragraph 4 is included and whether that phrase is used in subparagraph $f$ ) of paragraph 2 dealing with collective investment vehicles.]

79. The definition of "equivalent beneficiary" is relevant for the purposes of the derivative benefits test in paragraph 4 but may also be relevant for the purposes of subparagraph f) of paragraph 2 depending on how that rule is drafted.

80. Under the definition, a person may qualify as an "equivalent beneficiary" in two alternative ways.

81. Under the first alternative, a person may be an equivalent beneficiary because it is entitled to equivalent benefits under a tax treaty between the State of source and a third State in which the person is a resident. This alternative has two requirements. Under the first requirement in subdivision i)A), the person must be entitled to equivalent benefits under an applicable tax treaty. To satisfy that requirement, the person must be entitled to all the benefits of a 
comprehensive tax treaty between the Contracting State from which benefits of the Convention are claimed and a third State under provisions that are analogous to the rules in subparagraphs a), b) or d), or subdivision i) of subparagraph c), of paragraph 2. If the treaty in question does not have a comprehensive limitation on benefits article, this requirement is met only if the person would be entitled to treaty benefits under the tests in subparagraphs a), b) or d), or subdivision i) of subparagraph c), of paragraph 2 if that person were a resident of one of the Contracting States.

82. The second requirement in subdivision i)B) applies only with respect to benefits applicable to dividends, interest and royalties. Under that additional requirement, the person must be entitled to a rate of tax that is at least as low as the tax rate that would apply under the Convention to such income. Thus, the rates to be compared are: (1) the rate of tax that the source State would have imposed if a resident of the other Contracting State who is a qualified person were the beneficial owner of the income; and (2) the rate of tax that the source State would have imposed if the third State resident received the income directly from the source State.

83. The requirement in subdivision i)A) that a person be entitled to "all the benefits" of a comprehensive tax treaty eliminates those persons that qualify for benefits with respect to only certain types of income. Assume, for example, that company $\mathrm{CCO}$, a resident of State $C$, is the parent of $A C O$, a company resident of State $A . C C O$ is engaged in the active conduct of a business in State $C$ and, for that reason, would be entitled to the benefits of a treaty between State $C$ and State $B$ if it received dividends directly from a State $B$ subsidiary of ACO. This, however, is not sufficient for the purposes of the application of subdivision i)B) of the treaty between State $A$ and State B. Also, CCO cannot be an equivalent beneficiary if it qualifies for benefits only with respect to certain income as a result of a "derivative benefits" provision in the treaty between State $A$ and State $C$. However, it would be possible to look through $\mathrm{CCO}$ to its own parent company in order to determine whether that parent company is an equivalent beneficiary.

84. The second alternative for satisfying the "equivalent beneficiary" test in subdivision ii) is available only to residents of one of the Contracting States. These residents are equivalent beneficiaries if they are eligible for treaty benefits by reason of subparagraphs a), b) or d), or subdivision i) of subparagraph c), of paragraph 2. Thus, an individual resident of one Contracting State will be an equivalent beneficiary without regard to whether the individual would have been entitled to receive the same benefits if he had received the income 
directly. This second alternative clarifies that ownership by certain residents of a Contracting State would not disqualify a company from qualifying for treaty benefits under paragraph 4. Thus, for example, if 90 per cent of a company resident of State $A$ is owned by five companies that are resident in State $C$ and that satisfy the requirements of subdivision $i$ ) of the definition, and 10 per cent of the company is owned by an individual resident of State A or State B, then the company still can satisfy the requirements of subparagraph a) of paragraph 4.

The term "dual listed company arrangement"-subparagraph g)

g) the term "dual listed company arrangement" means an arrangement pursuant to which two publicly listed companies, while maintaining their separate legal entity status, shareholdings and listings, align their strategic directions and the economic interests of their respective shareholders through:

i) the appointment of common (or almost identical) boards of directors, except where relevant regulatory requirements prevent this;

ii) management of the operations of the two companies on a unified basis;

iii) equalised distributions to shareholders in accordance with an equalisation ratio applving between the two companies, including in the event of a winding up of one or both of the companies;

iv) the shareholders of both companies voting in effect as a single decision-making body on substantial issues affecting their combined interests; and

v) cross-guarantees as to, or similar financial support for, each other's material obligations or operations except where the effect of the relevant regulatorv requirements prevents such guarantees or financial support;

85. The term "dual listed company arrangement" is relevant for the purposes of the definition of the term "principal class of shares", which itself is relevant for the purposes of the provisions of subparagraph c) of paragraph 2 under which certain publicly-listed companies are "qualified persons".

86. The definition refers to an arrangement, adopted by certain publicly-listed companies, that reflect a commonality of management, 
operations, shareholders' rights, purpose and mission through a series of agreements between two parent companies, each with its own stock exchange listing, together with special provisions in their respective articles of association including in some cases, for example, the creation of special voting shares. Under these structures, the position of the parent company shareholders is, as far as possible, the same as if they held shares in a single company, with the same dividend entitlement and same rights to participate in the assets of the dual listed companies in the event of a winding up. The various parts of the definition refer to the various features that identify these arrangements.

The term "shares"-subparagraph h)

h) with respect to entities that are not companies, the term "shares" means interests that are comparable to shares.

87. The Article does not contain an exhaustive definition of the term "shares", which, under paragraph 2 of Article 3, should generally have the meaning which it has under the domestic law of the State that applies the Article. Subparagraph h), however, provides that the term "shares", when used in the Article with respect to entities that do not issue shares (e.g. trusts), refers to interests that are comparable to shares. These will typically be beneficial interests that entitle their holders to a share of the income or assets of the entity. 
ii) Rules aimed at arrangements one of the principal purposes of which is to obtain treaty benefits

17. As previously indicated, the following rule, which incorporates principles already recognised in the Commentary on Article 1 of the OECD Model Tax Convention, provides a more general way to address treaty avoidance cases, including treaty-shopping situations that are not covered by the specific anti-abuse rule in subsection A.1(a)(i) above (such as certain conduit financing arrangements):

\section{ARTICLE X}

\section{ENTITLEMENT TO BENEFITS}

[Paragraphs 1 to 6: see subsection A.1(a)(i) above]

7. Notwithstanding the other provisions of this Convention, a benefit under this Convention shall not be granted in respect of an item of income or capital if it is reasonable to conclude, having regard to all relevant facts and circumstances, that obtaining that benefit was one of the principal purposes of any arrangement or transaction that resulted directly or indirectly in that benefit, unless it is established that granting that benefit in these circumstances would be in accordance with the object and purpose of the relevant provisions of this Convention.

\section{Commentary on the PPT rule}

1. Paragraph 7 mirrors the guidance in paragraphs 9.5, 22, 22.1 and 22.2 of the Commentary on Article 1. According to that guidance, the benefits of a tax convention should not be available where one of the principal purposes of certain transactions or arrangements is to secure a benefit under a tax treaty and obtaining that benefit in these circumstances would be contrary to the object and purpose of the relevant provisions of the tax convention. Paragraph 7 incorporates the principles underlying these paragraphs into the Convention itself in order to allow States to address cases of improper use of the Convention even if their domestic law does not allow them to do so in accordance with paragraphs 22 and 22.1 of the Commentary on Article 1; it also confirms the application of these principles for States whose domestic law already allows them to address such cases.

2. The provisions of paragraph 7 have the effect of denying a benefit under a tax convention where one of the principal purposes of an arrangement or transaction that has been entered into is to obtain a benefit under the convention. Where this is the case, however, the last part of the paragraph allows the person to whom the benefit would 
otherwise be denied the possibility of establishing that obtaining the benefit in these circumstances would be in accordance with the object and purpose of the relevant provisions of this Convention.

3. Paragraph 7 supplements and does not restrict in any way the scope or application of the provisions of paragraphs 1 to 6 (the limitation-on-benefits rule): a benefit that is denied in accordance with these paragraphs is not a "benefit under the Convention" that paragraph 7 would also deny.

4. Conversely, the fact that a person is entitled to benefits under paragraphs 1 to 6 does not mean that these benefits cannot be denied under paragraph 7. Paragraphs 1 to 6 are rules that focus primarily on the legal nature, ownership in, and general activities of, residents of a Contracting State. As illustrated by the example in the next paragraph, these rules do not imply that a transaction or arrangement entered into by such a resident cannot constitute an improper use of a treaty provision.

5. Paragraph 7 must be read in the context of paragraphs 1 to 6 and of the rest of the Convention, including its preamble. This is particularly important for the purposes of determining the object and purpose of the relevant provisions of the Convention. Assume, for instance, that a public company whose shares are regularly traded on a recognized stock exchange in the Contracting State of which the company is a resident derives income from the other Contracting State. As long as that company is a "qualified person" as defined in paragraph 2, it is clear that the benefits of the Convention should not be denied solely on the basis of the ownership structure of that company, e.g. because a majority of the shareholders in that company are not residents of the same State. The object and purpose of subparagraph 2 c) is to establish a threshold for the treaty entitlement of public companies whose shares are held by residents of different States. The fact that such a company is a qualified person does not mean, however, that benefits could not be denied under paragraph 7 for reasons that are unrelated to the ownership of the shares of that company. Assume, for instance, that such a public company is a bank that enters into a conduit financing arrangement intended to provide indirectly to a resident of a third State the benefit of lower source taxation under a tax treaty. In that case, paragraph 7 would apply to deny that benefit because subparagraph 2 c), when read in the context of the rest of the Convention and, in particular, its preamble, cannot be considered as having the purpose, shared by the two Contracting States, of authorizing treaty-shopping transactions entered into by public companies. 
6. The provisions of paragraph 7 establish that a Contracting State may deny the benefits of a tax convention where it is reasonable to conclude, having considered all the relevant facts and circumstances, that one of the principal purposes of an arrangement or transaction was for a benefit under a tax treaty to be obtained. The provision is intended to ensure that tax conventions apply in accordance with the purpose for which they were entered into, i.e. to provide benefits in respect of bona fide exchanges of goods and services, and movements of capital and persons as opposed to arrangements whose principal objective is to secure a more favourable tax treatment.

7. The term "benefit" includes all limitations (e.g. a tax reduction, exemption, deferral or refund) on taxation imposed on the State of source under Articles 6 through 22 of the Convention, the relief from double taxation provided by Article 23, and the protection afforded to residents and nationals of a Contracting State under Article 24 or any other similar limitations. This includes, for example, limitations on the taxing rights of a Contracting State in respect of dividends, interest or royalties arising in that State, and paid to a resident of the other State (who is the beneficial owner) under Article 10, 11 or 12. It also includes limitations on the taxing rights of a Contracting State over a capital gain derived from the alienation of movable property located in that State by a resident of the other State under Article 13. When a tax convention includes other limitations (such as a tax sparing provision), the provisions of this Article also apply to that benefit.

8. The phrase "that resulted directly or indirectly in that benefit" is deliberately broad and is intended to include situations where the person who claims the application of the benefits under a tax treaty may do so with respect to a transaction that is not the one that was undertaken for one of the principal purposes of obtaining that treaty benefit. This is illustrated by the following example:

TCo, a company resident of State T, has acquired all the shares and debts of SCo, a company resident of State $S$, that were previously held by SCo's parent company. These include a loan made to SCo at 4 per cent interest payable on demand. State T does not have a tax convention with State $S$ and, therefore, any interest paid by SCo to TCo is subject to a withholding tax on interest at a rate of 25 per cent in accordance with the domestic law of State $S$. Under the State R-State $S$ tax convention, however, there is no withholding tax on interest paid by a company resident of a Contracting State and beneficially owned by a company resident of the other State; also, that treaty does not include provisions similar to paragraphs 1 to 6. TCo decides to transfer the loan to RCo, a 
subsidiary resident of State $R$, in exchange for three promissory notes payable on demand on which interest is payable at 3.9 per cent.

In this example, whilst RCo is claiming the benefits of the State $R$ State $S$ treaty with respect to a loan that was entered into for valid commercial reasons, if the facts of the case show that one of the principal purposes of TCo in transferring its loan to RCo was for RCo to obtain the benefit of the State $R$ - State $S$ treaty, then the provision would apply to deny that benefit as that benefit would result indirectly from the transfer of the loan.

9. The terms "arrangement or transaction" should be interpreted broadly and include any agreement, understanding, scheme, transaction or series of transactions, whether or not they are legally enforceable. In particular they include the creation, assignment, acquisition or transfer of the income itself, or of the property or right in respect of which the income accrues. These terms also encompass arrangements concerning the establishment, acquisition or maintenance of a person who derives the income, including the qualification of that person as a resident of one of the Contracting States, and include steps that persons may take themselves in order to establish residence. An example of an "arrangement" would be where steps are taken to ensure that meetings of the board of directors of a company are held in a different country in order to claim that the company has changed its residence. One transaction alone may result in a benefit, or it may operate in conjunction with a more elaborate series of transactions that together result in the benefit. In both cases the provisions of paragraph 7 may apply.

10. To determine whether or not one of the principal purposes of any person concerned with an arrangement or transaction is to obtain benefits under the Convention, it is important to undertake an objective analysis of the aims and objects of all persons involved in putting that arrangement or transaction in place or being a party to it. What are the purposes of an arrangement or transaction is a question of fact which can only be answered by considering all circumstances surrounding the arrangement or event on a case by case basis. It is not necessary to find conclusive proof of the intent of a person concerned with an arrangement or transaction, but it must be reasonable to conclude, after an objective analysis of the relevant facts and circumstances, that one of the principal purposes of the arrangement or transaction was to obtain the benefits of the tax convention. It should not be lightly assumed, however, that obtaining a benefit under a tax treaty was one of the principal purposes of an arrangement or transaction and merely 
reviewing the effects of an arrangement will not usually enable a conclusion to be drawn about its purposes. Where, however, an arrangement can only be reasonably explained by a benefit that arises under a treaty, it may be concluded that one of the principal purposes of that arrangement was to obtain the benefit.

11. A person cannot avoid the application of this paragraph by merely asserting that the arrangement or transaction was not undertaken or arranged to obtain the benefits of the Convention. All of the evidence must be weighed to determine whether it is reasonable to conclude that an arrangement or transaction was undertaken or arranged for such purpose. The determination requires reasonableness, suggesting that the possibility of different interpretations of the events must be objectively considered.

12. The reference to "one of the principal purposes" in paragraph 7 means that obtaining the benefit under a tax convention need not be the sole or dominant purpose of a particular arrangement or transaction. It is sufficient that at least one of the principal purposes was to obtain the benefit. For example, a person may sell a property for various reasons, but if before the sale, that person becomes a resident of one of the Contracting States and one of the principal purposes for doing so is to obtain a benefit under a tax convention, paragraph 7 could apply notwithstanding the fact that there may also be other principal purposes for changing the residence, such as facilitating the sale of the property or the re-investment of the proceeds of the alienation.

13. A purpose will not be a principal purpose when it is reasonable to conclude, having regard to all relevant facts and circumstances, that obtaining the benefit was not a principal consideration and would not have justified entering into any arrangement or transaction that has, alone or together with other transactions, resulted in the benefit. In particular, where an arrangement is inextricably linked to a core commercial activity, and its form has not been driven by considerations of obtaining a benefit, it is unlikely that its principal purpose will be considered to be to obtain that benefit. Where, however, an arrangement is entered into for the purpose of obtaining similar benefits under a number of treaties, it should not be considered that obtaining benefits under other treaties will prevent obtaining one benefit under one treaty from being considered a principal purpose for that arrangement. Assume, for example, that a taxpayer resident of State A enters into a conduit arrangement with a financial institution resident of State $B$ in order for that financial institution to invest, for the ultimate benefit of that taxpayer, in bonds issued in a large number of States with which State B, but not State A, has tax treaties. If the facts and circumstances 
reveal that the arrangement has been entered into for the principal purpose of obtaining the benefits of these tax treaties, it should not be considered that obtaining a benefit under one specific treaty was not one of the principal purposes for that arrangement. Similarly, purposes related to the avoidance of domestic law should not be used to argue that obtaining a treaty benefit was merely accessory to such purposes.

14. The following examples illustrate the application of the paragraph:

- Example A: TCo, a company resident of State T, owns shares of SCo, a company listed on the stock exchange of State S. State T does not have a tax convention with State $S$ and, therefore, any dividend paid by SCo to TCo is subject to a withholding tax on dividends of 25 per cent in accordance with the domestic law of State $S$. Under the State $R-S t a t e S$ tax convention, however, there is no withholding tax on dividends paid by a company resident of a Contracting State and beneficially owned by a company resident of the other State. TCo enters into an agreement with $R C o$, an independent financial institution resident of State $R$, pursuant to which TCo assigns to RCo the right to the payment of dividends that have been declared but have not yet been paid by SCo.

In this example, in the absence of other facts and circumstances showing otherwise, it would be reasonable to conclude that one of the principal purposes for the arrangement under which TCo assigned the right to the payment of dividends to RCo was for $R C o$ to obtain the benefit of the exemption from source taxation of dividends provided for by the State R-State $S$ tax convention and it would be contrary to the object and purpose of the tax convention to grant the benefit of that exemption under this treaty-shopping arrangement.

- Example B: SCo, a company resident of State $S$, is the subsidiary of TCo, a company resident of State T. State T does not have a tax convention with State $S$ and, therefore, any dividend paid by SCo to TCo is subject to a withholding tax on dividends of 25 per cent in accordance with the domestic law of State S. Under the State $R$-State $S$ tax convention, however, the applicable rate of withholding tax on dividends paid by a company of State $S$ to a resident of State $R$ is 5 per cent. TCo therefore enters into an agreement with $R C o$, a financial institution resident of State $R$ and a qualified person under subparagraph 3 a) of this Article, pursuant to which RCo acquires the usufruct of newly issued 
non-voting preferred shares of SCo for a period of three years. TCo is the bare owner of these shares. The usufruct gives RCo the right to receive the dividends attached to these preferred shares. The amount paid by RCo to acquire the usufruct corresponds to the present value of the dividends to be paid on the preferred shares over the period of three years (discounted at the rate at which TCo could borrow from RCo).

In this example, in the absence of other facts and circumstances showing otherwise, it would be reasonable to conclude that one of the principal purposes for the arrangement under which RCo acquired the usufruct of the preferred shares issued by SCo was to obtain the benefit of the 5 per cent limitation applicable to the source taxation of dividends provided for by the State R-State $S$ tax convention and it would be contrary to the object and purpose of the tax convention to grant the benefit of that limitation under this treaty-shopping arrangement.

- Example C: RCo, a company resident of State $R$, is in the business of producing electronic devices and its business is expanding rapidly. It is now considering establishing a manufacturing plant in a developing country in order to benefit from lower manufacturing costs. After a preliminary review, possible locations in three different countries are identified. All three countries provide similar economic and political environments. After considering the fact that State $S$ is the only one of these countries with which State R has a tax convention, the decision is made to build the plant in that State.

In this example, whilst the decision to invest in State $S$ is taken in the light of the benefits provided by the State R-State $S$ tax convention, it is clear that the principal purposes for making that investment and building the plant are related to the expansion of RCo's business and the lower manufacturing costs of that country. In this example, it cannot reasonably be considered that one of the principal purposes for building the plant is to obtain treaty benefits. In addition, given that a general objective of tax conventions is to encourage cross-border investment, obtaining the benefits of the State R-State S convention for the investment in the plant built in State $S$ is in accordance with the object and purpose of the provisions of that convention.

- Example D: RCo, a collective investment vehicle resident of State $R$, manages a diversified portfolio of investments in the international financial market. RCo currently holds 15 per cent 
of its portfolio in shares of companies resident of State $S$, in respect of which it receives annual dividends. Under the tax convention between State $R$ and State $S$, the withholding tax rate on dividends is reduced from 30 per cent to 10 per cent.

RCo's investment decisions take into account the existence of tax benefits provided under State $R$ 's extensive tax convention network. A majority of investors in RCo are residents of State $R$, but a number of investors (the minority investors) are residents of States with which State $S$ does not have a tax convention. Investors' decisions to invest in RCo are not driven by any particular investment made by RCo, and RCo's investment strategy is not driven by the tax position of its investors. RCo annually distributes almost all of its income to its investors and pays taxes in State $R$ on income not distributed during the year.

In making its decision to invest in shares of companies resident of State S, RCo considered the existence of a benefit under the State $R$-State $S$ tax convention with respect to dividends, but this alone would not be sufficient to trigger the application of paragraph 7. The intent of tax treaties is to provide benefits to encourage cross-border investment and, therefore, to determine whether or not paragraph 7 applies to an investment, it is necessary to consider the context in which the investment was made. In this example, unless RCo's investment is part of an arrangement or relates to another transaction undertaken for a principal purpose of obtaining the benefit of the Convention, it would not be reasonable to deny the benefit of the State R-State $S$ tax treaty to $R$ Co.

- Example E: RCo is a company resident of State $R$ and, for the last 5 years, has held 24 per cent of the shares of company SCo, a resident of State $S$. Following the entry-into-force of a tax treaty between States $R$ and $S$ (Article 10 of which is identical to Article 10 of this Model), RCo decides to increase to 25 per cent its ownership of the shares of SCo. The facts and circumstances reveal that the decision to acquire these additional shares has been made primarily in order to obtain the benefit of the lower rate of tax provided by Article 10(2)a) of the treaty.

In that case, although one of the principal purposes for the transaction through which the additional shares are acquired is clearly to obtain the benefit of Article 10(2)a), paragraph 7 would not apply because it may be established that granting that benefit in these circumstances would be in accordance with the object 
and purpose of Article 10(2)a). That subparagraph uses an arbitrary threshold of 25 per cent for the purposes of determining which shareholders are entitled to the benefit of the lower rate of tax on dividends and it is consistent with this approach to grant the benefits of the subparagraph to a taxpayer who genuinely increases its participation in a company in order to satisfy this requirement.

15. For various reasons, some States may be unable to accept the rule included in paragraph 7. These States, however, may wish to supplement the limitation-on-benefits rule of paragraphs 1 to 6 by a narrower version of paragraph 7 in order to address treaty-shopping strategies commonly referred to as "conduit arrangements" that would not be caught by the limitation-on-benefits rule. States wishing to do so could provide that the benefits of the provisions of the Convention, or of some of them (e.g. those of Articles 7, 10,11, 12 and 21), will not be accorded in respect of any income obtained under, or as part of, a conduit arrangement. The following is an example of a definition of "conduit arrangement" that could be used for the purposes of such a rule:

The term "conduit arrangement" means a transaction or series of transactions:

a) which is structured in such a way that a resident of a Contracting State entitled to the benefits of this Convention receives an item of income arising in the other Contracting State but that resident pays, directly or indirectly, all or substantially all of that income (at any time or in any form) to one or more persons who are not resident of either Contracting State and who, if they received that item of income direct from the other Contracting State, would not be entitled under a convention for the avoidance of double taxation between the State of which those persons are resident and the Contracting State in which the income arises, or otherwise, to benefits with respect to that item of income which are equivalent to, or more favourable than, those available under this Convention to a resident of a Contracting State; and

b) which has as one of its principal purposes obtaining such increased benefits as are available under this Convention. 
b) Other situations where a person seeks to circumvent treaty limitations

18. Apart from the requirement that a person be a resident of a Contracting State, other conditions must be satisfied in order to obtain the benefit of certain provisions of tax treaties. In certain cases, it may be possible to enter into transactions for the purposes of satisfying these conditions in circumstances where it would be inappropriate to grant the relevant treaty benefits. Although the general anti-abuse rule in subsection A.1(a)(ii) above will be useful in addressing such situations, targeted specific treaty anti-abuse rules generally provide greater certainty for both taxpayers and tax administrations. Such rules are already found in some Articles of the Model Tax Convention (see, for example, Articles 13(4) and 17(2)). In addition, the Commentary suggests the inclusion of other antiabuse provisions in certain circumstances (see, for example, paragraphs 16 and 17 of the Commentary on Article 10). Other anti-abuse provisions are found in bilateral treaties concluded by OECD and non-OECD countries.

19. The following are examples of situations with respect to which specific treaty anti-abuse rules may be helpful and proposals for changes intended to address some of these situations.

\section{i) Splitting-up of contracts}

20. Paragraph 18 of the Commentary on Article 5 indicates that "[t]he twelve-month threshold [of Article 5(3)] has given rise to abuses; it has sometimes been found that enterprises (mainly contractors or subcontractors working on the continental shelf or engaged in activities connected with the exploration and exploitation of the continental shelf) divided their contracts up into several parts, each covering a period less than twelve months and attributed to a different company which was, however, owned by the same group."

21. The paragraph provides that although such abuses may be addressed by legislative or judicial anti-avoidance rules, countries may deal with them through bilateral solutions. Whilst it was suggested that an alternative provision could be added to paragraph 18 for that purpose, ${ }^{10}$ it was concluded that transactions aimed at circumventing the permanent establishment threshold should be examined as part of the work on Action 7 (Prevent the artificial avoidance of PE status).

\section{ii) Hiring-out of labour cases}

22. Hiring-out of labour cases, where the taxpayer attempts to obtain inappropriately the benefits of the exemption from source taxation provided 
for in Article 15(2), are dealt with in paragraphs 8.1 to 8.28 of the Commentary on Article 15. It was concluded that the guidance already found in these paragraphs, and in particular the alternative provision found in paragraph 8.3 of that Commentary, dealt adequately with this type of treaty abuse.

\section{iii) Transactions intended to avoid dividend characterisation}

23. In some cases, transactions may be entered into for the purpose of avoiding domestic law rules that characterise a certain item of income as a dividend and to benefit from a treaty characterisation of that income (e.g. as capital gain) that prevents source taxation.

24. As part of its work on hybrid mismatch arrangements, Working Party 1 has examined whether the treaty definitions of dividends and interest could be amended, as is done in some treaties, in order to permit the application of domestic law rules that characterise an item of income as such. Although it was concluded that such a change would have a very limited impact with respect to hybrid mismatch arrangements, it was decided to further examine the possibility of making such changes when other parts of the work on the BEPS Action Plan (e.g. Action 4) will have progressed.

\section{iv) Dividend transfer transactions}

25. In these transactions, a taxpayer entitled to the 15 per cent portfolio rate of Article $10(2) b$ ) seeks to obtain the 5 per cent direct dividend rate of Article $10(2) a$ ) or the 0 per cent rate that some bilateral conventions provide for dividends paid to pension funds (see paragraph 69 of the Commentary on Article 18).

26. Paragraphs 16 and 17 of the Commentary on Article 10 deal with transactions through which a taxpayer tries to access the lower rate of 5 per cent applicable to dividends:

16. Subparagraph $a$ ) of paragraph 2 does not require that the company receiving the dividends must have owned at least 25 per cent of the capital for a relatively long time before the date of the distribution. This means that all that counts regarding the holding is the situation prevailing at the time material for the coming into existence of the liability to the tax to which paragraph 2 applies, i.e. in most cases the situation existing at the time when the dividends become legally available to the shareholders. The primary reason for this resides in the desire to have a provision which is applicable as broadly as possible. To require the parent company to have 
possessed the minimum holding for a certain time before the distribution of the profits could involve extensive inquiries. Internal laws of certain OECD member countries provide for a minimum period during which the recipient company must have held the shares to qualify for exemption or relief in respect of dividends received. In view of this, Contracting States may include a similar condition in their conventions.

17. The reduction envisaged in subparagraph $a$ ) of paragraph 2 should not be granted in cases of abuse of this provision, for example, where a company with a holding of less than 25 per cent has, shortly before the dividends become payable, increased its holding primarily for the purpose of securing the benefits of the abovementioned provision, or otherwise, where the qualifying holding was arranged primarily in order to obtain the reduction. To counteract such manoeuvres Contracting States may find it appropriate to add to subparagraph a) a provision along the following lines:

provided that this holding was not acquired primarily for the purpose of taking advantage of this provision.

27. It was concluded that in order to deal with such transactions, a minimum shareholding period should be included in subparagraph $a$ ) of Article 10(2), which should therefore be amended to read as follows:

a) 5 per cent of the gross amount of the dividends if the beneficial owner is a company (other than a partnership) which holds directly at least 25 per cent of the capital of the company paying the dividends throughout a 365 day period that includes the day of the payment of the dividend (for the purpose of computing that period, no account shall be taken of changes of ownership that would directly result from a corporate reorganisation, such as a merger or divisive reorganisation, of the company that holds the shares or that pays the dividend);

28. It was also concluded that additional anti-abuse rules should be included in Article 10 to deal with cases where certain intermediary entities established in the State of source are used to take advantage of the treaty provisions that lower the source taxation of dividends.

29. For example, paragraph 67.4 of the Commentary on Article 10 includes an alternative provision that may be included to prevent access to

- $\quad$ the 5 per cent rate in the case of dividends paid by a domestic REIT to a non-resident portfolio investor, and 
- $\quad$ both the 5 per cent and the 15 per cent rates in the case of dividends paid by a domestic REIT to a non-resident investor who holds directly or indirectly more than 10 per cent of the REIT's capital.

30. Another example, found in U.S. treaty practice, is a provision that denies the application of the 5 per cent rate in the case of dividends paid to a non-resident company by a U.S. Regulated Investment Company (RIC) even if that non-resident company holds more than 10 per cent of the shares of the RIC.

31. Based on these examples, where the domestic law of a Contracting State allows the possibility that portfolio investments in shares of companies of that State be made through certain collective investment vehicles which are established in that State and which do not pay tax on their investment income so that a non-resident investor in such a vehicle is able to access the lower treaty rate applicable to dividends with respect to distributions made by that collective investment vehicle, it is recommended that a specific anti-abuse rule be included in Article 10. Such a rule might be drafted along the following lines:

Subparagraph $2 a$ ) shall not apply to dividends paid by a resident of [name of the State] that is a [description of the type of collective investment vehicle to which that rule should apply]

v) Transactions that circumvent the application of Article 13(4)

32. Article 13(4) allows the Contracting State in which immovable property is situated to tax capital gains realised by a resident of the other State on shares of companies that derive more than 50 per cent of their value from such immovable property.

33. Paragraph 28.5 of the Commentary on Article 13 already provides that States may want to consider extending the provision to cover not only gains from shares but also gains from the alienation of interests in other entities, such as partnerships or trusts, which would address one form of abuse. It was agreed that Article 13(4) should be amended to include such wording.

34. There might also be cases, however, where assets are contributed to an entity shortly before the sale of the shares or other interests in that entity in order to dilute the proportion of the value of these shares or interests that is derived from immovable property situated in one Contracting State. In order to address such cases, it was agreed that Article 13(4) should be amended to refer to situations where shares or similar interests derive their value primarily 
from immovable property at any time during a certain period as opposed to at the time of the alienation only.

35. The following revised version of paragraph 4 of Article 13 incorporates these changes:

4. Gains derived by a resident of a Contracting State from the alienation of shares or comparable interests, such as interests in a partnership or trust, may be taxed in the other Contracting State if, at any time during the 365 days preceding the alienation, these shares or comparable interests derived deriving-more than 50 per cent of their value directly or indirectly from immovable property, as defined in Article 6, situated in that the other State-may be taxed in that other State.

vi) Tie-breaker rule for determining the treaty residence of dual-resident persons other than individuals

36. One of the key limitations on the granting of treaty benefits is the requirement that a person be a resident of a Contracting State for the purposes of the relevant tax treaty. Under Article 4(1) of the OECD Model Tax Convention, the treaty residence of a person is dependent on the domestic tax laws of each Contracting State, which may result in a person being resident of both States. In such cases, Article 4(2) determines a single treaty residence in the case of individuals. Article 4(3), which does the same for persons other than individuals, provides that the dual-resident person "shall be deemed to be a resident only of the State in which its place of effective management is situated".

37. When this rule was originally included in the 1963 Draft Convention, the OECD Fiscal Committee expressed the view that "it may be rare in practice for a company, etc. to be subject to tax as a resident in more than one State" $" 11$ but because that was possible, "special rules as to the preference" were needed.

38. The 2008 Update to the OECD Model Tax Convention introduced an alternative version of Article 4(3) (see paragraphs 24 and 24.1 of the Commentary on Article 4) according to which the competent authorities of the Contracting States shall, having regard to a number of relevant factors, endeavour to determine by mutual agreement the State of which the person is a resident for the purposes of the Convention. When that alternative was discussed, the view of many countries was that cases where a company is a dual-resident often involve tax avoidance arrangements. For that reason, it is proposed that the current rule found in Article 4(3) be replaced by the 
alternative found in the Commentary, which allows a case-by-case solution of these cases.

39. The following are the changes that are proposed for that purpose:

Replace paragraph 3 of Article 4 of the Model Tax Convention by the following:

3. Where by reason of the provisions of paragraph 1 a person other than an individual is a resident of both Contracting States, then it shatl be deemed to be a resident only of the State in which its place of effective management is situated. the competent authorities of the Contracting States shall endeavour to determine by mutual agreement the Contracting State of which such person shall be deemed to be a resident for the purposes of the Convention, having regard to its place of effective management, the place where it is incorporated or otherwise constituted and any other relevant factors. In the absence of such agreement, such person shall not be entitled to any relief or exemption from tax provided by this Convention except to the extent and in such manner as may be agreed upon by the competent authorities of the Contracting States.

Replace paragraphs 21 to 24.1 of the Commentary on Article 4 by the following:

21. This paragraph concerns companies and other bodies of persons, irrespective of whether they are or not legal persons. Cases where a company, etc. is subject to tax as a resident in more than one State may occur if, for instance, one State attaches importance to the registration and the other State to the place of effective management. So, in the case of companies, etc., also, special rules as to the preference must be established.

22. When paragraph 3 was first drafted, it was considered that $i \mathrm{Ft}$ would not be an adequate solution to attach importance to a purely formal criterion like registration. and preference was given to a rule based on the place of effective management, which was intended to be based on Therefore paragraph 3 attaches importance to the place where the company, etc. was is actually managed.

23. The formulation of the preference criterion in the case of persens other than individuats was considered in particular in connection with the taxation of income from shipping, inland waterways transport and air transport. A number of conventions for the avoidance of double taxation on such income accord the taxing power to the State in which the "place of management" of the enterprise is situated; other conventions attach importance to its "place of effective 
management", others again to the "fiscal domicile of the operator". In [2014], however, the Committee on Fiscal Affairs recognised that although situations of double residence of entities other than individuals were relatively rare, there had been a number of tax avoidance cases involving dual resident companies. It therefore concluded that a better solution to the issue of dual residence of entities other than individuals was to deal with such situations on a case-by-case basis.

24. As a result of these considerations, the current version of paragraph 3 provides that the competent authorities of the Contracting States shall endeavour to resolve by mutual agreement cases of dual residence of a person other than an individual. the "place of effective management" has been adopted as the preference eriterion for persons other than individuals. The place of effective management is the place where key management and commercial decisions that are necessary for the conduct of the entity's business as a whole are in substance made. All relevant facts and cireumstances must be examined to determine the place of effective management. An entity may have more than one place of management, but it can have only one place of effective management at any one time.

24.1 Some countries, however, consider that cases of duat residence of persens who are not individuals are relatively rare and should be dealt with on a case by-case basis. Some countries also consider that such a case-by-case approach is the best way to deal with the difficulties in determining the place of effective management of a legal person that may arise from the use of new communication technologies. These countries are free to leave the question of the residence of these persons to be settled by the competent authorities, which can be done by replacing the paragraph by the following provision:

3. Where by reasen of the provisions of paragraph 1 a persen other than an individual is a resident of both Contracting States, the competent authorities of the Contracting States shall endeavour to determine by mutual agreement the Contracting State of which such person shall be deemed to be a resident for the purposes of the Convention, having regard to its place of effective management, the place where it is incorporated or otherwise constituted and any other relevant factors. In the absence of such agreement, such person shall not be entitled to any relief or exemption from tax provided by this Convention except to the extent and in such manner as may be agreed upon by the competent authorities of the Contracting State. 
Competent authorities having to apply paragraph 3 such a provision to determine the residence of a legal person for purposes of the Convention-would be expected to take account of various factors, such as where the meetings of the person's its-board of directors or equivalent body are usually held, where the chief executive officer and other senior executives usually carry on their activities, where the senior day-to-day management of the person is carried on, where the person's headquarters are located, which country's laws govern the legal status of the person, where its accounting records are kept, whether determining that the legal person is a resident of one of the Contracting States but not of the other for the purpose of the Convention would carry the risk of an improper use of the provisions of the Convention etc. Countries that consider that the competent authorities should not be given the discretion to solve such cases of dual residence without an indication of the factors to be used for that purpose may want to supplement the provision to refer to these or other factors that they consider relevant. Also, since the application of the provision would normally be requested by the person concerned through the mechanism provided for under paragraph 1 of Article 25, the request should be made within three years from the first notification to that person that its taxation is not in accordance with the Convention since it is considered to be a resident of both Contracting States. Since the facts on which a decision will be based may change over time, the competent authorities that reach a decision under that provision should clarify which period of time is covered by that decision.

24.2 Some States, however, consider that it is preferable to deal with cases of dual residence of entities through the rule based on the "place of effective management" that was included in the Convention before [next update]. These States also consider that this rule can be interpreted in a way that prevents it from being abused. States that share that view and that agree on how the concept of "place of effective management" should be interpreted are free to include in their bilateral treaty the following version of paragraph 3 :

Where by reason of the provisions of paragraph 1 a person other than an individual is a resident of both Contracting States, then it shall be deemed to be a resident only of the State in which its place of effective management is situated. 


\section{vii) Anti-abuse rule for permanent establishments situated in} third States

40. Paragraph 32 of the Commentary on Article 10, paragraph 25 of the Commentary on Article 11 and paragraph 21 of the Commentary on Article 12 refer to potential abuses that may result from the transfer of shares, debt-claims, rights or property to permanent establishments set up solely for that purpose in countries that offer preferential treatment to the income from such assets. Where the State of residence exempts, or taxes at low rates, profits of such permanent establishments situated in third States, the State of source should not be expected to grant treaty benefits with respect to that income.

41. The last part of paragraph 71 of the Commentary on Article 24 deals with that situation and suggests that an anti-abuse provision could be included in bilateral conventions to protect the State of source from having to grant treaty benefits where income obtained by a permanent establishment situated in a third State is not taxed normally in that State:

71. ... Another question that arises with triangular cases is that of abuses. If the Contracting State of which the enterprise is a resident exempts from tax the profits of the permanent establishment located in the other Contracting State, there is a danger that the enterprise will transfer assets such as shares, bonds or patents to permanent establishments in States that offer very favourable tax treatment, and in certain circumstances the resulting income may not be taxed in any of the three States. To prevent such practices, which may be regarded as abusive, a provision can be included in the convention between the State of which the enterprise is a resident and the third State (the State of source) stating that an enterprise can claim the benefits of the convention only if the income obtained by the permanent establishment situated in the other State is taxed normally in the State of the permanent establishment.

42. It was concluded that a specific anti-abuse provision should be included in the Model Tax Convention to deal with that and similar triangular cases where income attributable to the permanent establishment in a third State is subject to low taxation. The following provision has been drafted for that purpose.

\section{Where}

a) an enterprise of a Contracting State derives income from the other Contracting State and such income is attributable to a permanent establishment of the enterprise situated in a third jurisdiction, and 
b) the profits attributable to that permanent establishment are exempt from tax in the first-mentioned State

the tax benefits that would otherwise apply under the other provisions of the Convention will not apply to any item of income on which the tax in the third jurisdiction is less than 60 per cent of the tax that would be imposed in the first-mentioned State if the income were earned or received in that State by the enterprise and were not attributable to the permanent establishment in the third jurisdiction. In such a case

c) any dividends, interest, or royalties to which the provisions of this paragraph apply shall remain taxable according to the domestic law of the other State but the tax charged in that State shall not exceed [rate to be determined] per cent of the gross amount thereof, and

d) any other income to which the provisions of this paragraph apply shall remain taxable according to the domestic law of the other State, notwithstanding any other provision of the Convention.

The preceding provisions of this paragraph shall not apply if the income derived from the other State is

e) derived in connection with or is incidental to the active conduct of a business carried on through the permanent establishment (other than the business of making, managing or simply holding investments for the enterprise's own account, unless these activities are banking, insurance or securities activities carried on by a bank, insurance enterprise or registered securities dealer, respectively), or

f) royalties that are received as compensation for the use of, or the right to use, intangible property produced or developed by the enterprise through the permanent establishment.

Commentary on the provision

1. As mentioned in paragraph 32 of the Commentary on Article 10, paragraph 25 of the Commentary on Article 11 and paragraph 21 of the Commentary on Article 12, potential abuses may result from the transfer of shares, debt-claims, rights or property to permanent establishments set up solely for that purpose in countries that do not tax such investment income or offer preferential treatment to the income from such assets. Where the State of residence exempts the investment income of such permanent establishments situated in third States, the State of source should not be expected to grant treaty benefits with 
respect to such income. The proposed paragraph, which applies where a Contracting State exempts the investment income of enterprises of that State that are attributable to permanent establishments situated in a third State, provides that treaty benefits will not be granted in such cases. That rule does not apply to profits that are derived in connection with, or that are incidental to, the active conduct of a business through the permanent establishment, excluding an investment business that is not carried by a bank, insurance enterprise or securities dealer; it also does not apply if the income received from the State of source constitutes royalties received as compensation for the use of, or the right to use, intangible property produced or developed by the enterprise through the permanent establishment.

2. In any case where benefits are denied under this paragraph, the enterprise that derives the relevant income should have access to the discretionary relief provision of paragraph 5 of Article [X] in order to ensure that benefits may be granted where the establishment, acquisition or maintenance of the permanent establishment and the conduct of its operations did not have as one of its principal purposes the obtaining of benefits under this Convention. This result could be achieved by including this provision into Article [X].

3. Some States may prefer a more comprehensive solution that would not be restricted to situations where an enterprise of a Contracting State is exempt, in that State, on the profits attributable to a permanent establishment situated in a third State. In such a case, the provision would be applicable in any case where income derived from one Contracting State that is attributable to a permanent establishment situated in a third State is subject to combined taxation, in the State of the enterprise and the State of the permanent establishment, at an effective rate that is less than the 60 per cent threshold. The following is an example of a provision that could be used for that purpose:

Notwithstanding the other provisions of this Convention, where an enterprise of a Contracting State derives income from the other Contracting State and that income is attributable to a permanent establishment of that enterprise that is situated in a third State, the tax benefits that would otherwise apply under the other provisions of this Convention will not apply to that income if the profits of that permanent establishment are subject to a combined aggregate effective rate of tax in the first-mentioned Contracting State and third State that is less than 60 percent of the general rate of company tax applicable in the first-mentioned Contracting State. Any dividends, interest or royalties to which the provisions of this paragraph apply shall remain taxable in the other Contracting 
State at a rate that shall not exceed 15 percent of the gross amount thereof. Any other income to which the provisions of this paragraph apply shall remain taxable according to the laws of the other Contracting State notwithstanding any other provision of this Convention. The provisions of this paragraph shall not apply if:

a) in the case of royalties, the royalties are received as compensation for the use of, or the right to use, intangible property produced or developed by the enterprise through the permanent establishment; or

b) in the case of any other income, the income derived from the other Contracting State is derived in connection with, or is incidental to, the active conduct of a business carried on in the third State through the permanent establishment (other than the business of making, managing or simply holding investments for the enterprise's own account, unless these activities are banking, insurance or securities activities carried on by a bank, insurance enterprise or registered securities dealer, respectively).

\section{Cases where a person tries to abuse the provisions of} domestic tax law using treaty benefits

43. Many tax avoidance risks that threaten the tax base are not caused by tax treaties but may be facilitated by treaties. In these cases, it is not sufficient to address the treaty issues: changes to domestic law are also required. Avoidance strategies that fall into this category include:

- Thin capitalisation and other financing transactions that use tax deductions to lower borrowing costs;

- Dual residence strategies (e.g. a company is resident for domestic tax purposes but non-resident for treaty purposes);

- Transfer mispricing;

- Arbitrage transactions that take advantage of mismatches found in the domestic law of one State and that are

- related to the characterization of income (e.g. by transforming business profits into capital gain) or payments (e.g. by transforming dividends into interest);

- related to the treatment of taxpayers (e.g. by transferring income to tax-exempt entities or entities that have 
accumulated tax losses; by transferring income from nonresidents to residents);

- related to timing differences (e.g. by delaying taxation or advancing deductions).

- Arbitrage transactions that take advantage of mismatches between the domestic laws of two States and that are

- related to the characterization of income;

- related to the characterization of entities;

- related to timing differences.

- Transactions that abuse relief of double taxation mechanisms (by producing income that is not taxable in the State of source but must be exempted by the State of residence or by abusing foreign tax credit mechanisms).

44. Many of these transactions will be addressed through the work on other aspects of the Action Plan, in particular Action 2 (Neutralise the effects of hybrid mismatch arrangements), Action 3 (Strengthen CFC rules), Action 4 (Limit base erosion via interest deductions and other financial payments) and Actions 8, 9 and 10 dealing with Transfer Pricing.

45. The main objective of the work aimed at preventing the granting of treaty benefits with respect to these transactions is to ensure that treaties do not prevent the application of specific domestic law provisions that would prevent these transactions. ${ }^{12}$ Granting the benefits of these treaty provisions in such cases would be inappropriate to the extent that the result would be the avoidance of domestic tax. Such cases include situations where it is argued that

- Provisions of a tax treaty prevent the application of a domestic GAAR;

- Article 24(4) and Article 24(5) prevent the application of domestic thin-capitalisation rules;

- Article 7 and/or Article 10(5) prevent the application of CFC rules;

- Article 13(5) prevents the application of exit or departure taxes;

- Article 24(5) prevents the application of domestic rules that restrict tax consolidation to resident entities;

- Article 13(5) prevents the application of dividend stripping rules targeted at transactions designed to transform dividends into treatyexempt capital gains; 
- Article 13(5) prevents the application of domestic assignment of income rules (such as grantor trust rules).

46. The Commentary already addresses a number of these issues. For instance, it deals expressly with CFC rules (paragraph 23 of the Commentary on Article 1 provides that treaties do not prevent the application of such rules). It also refers to thin capitalisation rules (paragraph 3 of the Commentary on Article 9 suggests that treaties do not prevent the application of such rules "insofar as their effect is to assimilate the profits of the borrower to an amount corresponding to the profits which would have accrued in an arm's length situation"). It does not, however, address a number of other specific domestic anti-abuse rules.

47. Paragraphs 22 and 22.1 of the Commentary on Article 1 of the OECD Model Tax Convention provide a more general discussion of the interaction between tax treaties and domestic anti-abuse rules. These paragraphs conclude that a conflict would not occur in the case of the application of certain domestic anti-abuse rules to a transaction that constitutes an abuse of the tax treaty:

22. Other forms of abuse of tax treaties (e.g. the use of a base company) and possible ways to deal with them, including "substanceover-form", "economic substance" and general anti-abuse rules have also been analysed, particularly as concerns the question of whether these rules conflict with tax treaties [...]

22.1 Such rules are part of the basic domestic rules set by domestic tax laws for determining which facts give rise to a tax liability; these rules are not addressed in tax treaties and are therefore not affected by them. Thus, as a general rule and having regard to paragraph 9.5 , there will be no conflict. [...]"

48. Paragraph 9.5 of the Commentary on Article 1 offers the following guidance as to what constitutes an abuse of the provisions of a tax treaty:

A guiding principle is that the benefits of a double taxation convention should not be available where a main purpose for entering into certain transactions or arrangements was to secure a more favourable tax position and obtaining that more favourable treatment in these circumstances would be contrary to the object and purpose of the relevant provisions.

49. As indicated in subsection A.1, this report recommends that a new general anti-abuse rule that will incorporate the principle already recognised in paragraph 9.5 of the Commentary on Article 1 be included in tax treaties. The incorporation of that principle into tax treaties will provide a clear 
statement that the Contracting States want to deny the application of the provisions of their treaty when transactions or arrangements are entered into in order to obtain the benefits of these provisions in inappropriate circumstances. The incorporation of that principle into a specific treaty provision does not modify, however, the conclusions already reflected in the Commentary on Article 1 concerning the interaction between treaties and domestic anti-abuse rules; such conclusions remain applicable, in particular with respect to treaties that do not incorporate the new general anti-abuse rule. This will be clarified through the addition of the following new paragraphs to the Commentary:

1. Paragraph 7 of Article [X] [the PPT rule] and the specific treaty anti-abuse rules included in tax treaties are not the only ways of addressing transactions and arrangements entered into for the purpose of obtaining treaty benefits in inappropriate circumstances. Domestic anti-abuse rules and judicial doctrines may also be used to address such transactions and arrangements. Also, in some cases, transactions or arrangements are entered into for the purpose of abusing both domestic laws and treaties; there might also be cases where tax treaties are used to facilitate the abuse of domestic law provisions (e.g. by protecting the taxpayer from the application of certain domestic anti-abuse rules).

2. For these reasons, domestic anti-abuse rules and judicial doctrines play an important role in preventing treaty benefits from being granted in inappropriate circumstances. The application of such domestic anti-abuse rules and doctrines, however, raises the issue of possible conflicts with treaty provisions. This issue is discussed below in relation to specific legislative anti-abuse rules, general legislative antiabuse rules and judicial doctrines.

Specific legislative anti-abuse rules

3. Tax authorities seeking to address the improper use of a tax treaty may first consider the application of specific anti-abuse rules included in their domestic tax law.

4. Many specific anti-abuse rules found in domestic law apply primarily in cross-border situations and may be relevant for the application of tax treaties. For instance, thin capitalization rules may apply to restrict the deduction of base-eroding interest payments to residents of treaty countries; transfer pricing rules (even if not designed primarily as anti-abuse rules) may prevent the artificial shifting of income from a resident enterprise to an enterprise that is resident of a treaty country; exit or departure taxes rules may prevent the avoidance of capital gains tax through a change of residence before the realisation of a treaty-exempt capital gain; dividend stripping rules may prevent the 
avoidance of domestic dividend withholding taxes through transactions designed to transform dividends into treaty-exempt capital gains; and anti-conduit rules may prevent certain avoidance transactions involving the use of conduit arrangements.

5. Generally, where the application of provisions of domestic law and of those of tax treaties produces conflicting results, the provisions of tax treaties are intended to prevail. This is a logical consequence of the principle of "pacta sunt servanda" which is incorporated in Article 26 of the Vienna Convention on the Law of Treaties. Thus, if the application of specific anti-abuse rules found in domestic law were to result in a tax treatment that is not in accordance with the provisions of a tax treaty, this would conflict with the provisions of that treaty and the provisions of the treaty should prevail under public international law. ${ }^{1}$

[Footnote to paragraph 5:] 1. Under Article 60 of the Vienna Convention on the Law of Treaties "[a] material breach of a bilateral treaty by one of the parties entitles the other to invoke the breach as a ground for terminating the treaty or suspending its operation in whole or in part".

6. As explained below, however, such conflicts will often be avoided and each case must be analysed based on its own circumstances.

7. First, a treaty may specifically allow the application of certain types of specific domestic anti-abuse rules. For example, Article 9 specifically authorises the application of domestic transfer pricing rules in the circumstances defined by that Article. Also, many treaties include specific provisions clarifying that there is no conflict or, even if there is a conflict, allowing the application of the domestic rules. This would be the case, for example, for a treaty rule that expressly allows the application of a thin capitalisation rule found in the domestic law of one or both Contracting States.

8. Second, many provisions of the Convention depend on the application of domestic law. This is the case, for instance, for the determination of the residence of a person (see paragraph 1 of Article 4), the determination of what is immovable property (see paragraph 2 of Article 6) and the determination of when income from corporate rights might be treated as a dividend (see paragraph 3 of Article 10). More generally, paragraph 2 of Article 3 makes domestic rules relevant for the purposes of determining the meaning of terms that are not defined in the Convention. In many cases, therefore, the application of specific anti-abuse rules found in domestic law will have an impact on how the treaty provisions are applied rather than produce conflicting results. This would be the case, for example, if a domestic law provision treats 
the profits realised by a shareholder when a company redeems some of its shares as dividends: although such a redemption could be considered to constitute an alienation for the purposes of paragraph 5 of Article 13, paragraph 28 of the Commentary on Article 10 recognises that such profits will constitute dividends for the purposes of Article 10 if the profits are treated as dividends under domestic law.

9. Third, the application of tax treaty provisions in a case that involves an abuse of these provisions may be denied under paragraph 7 of Article [X] [the PPT rule] or, in the case of a treaty that does not include that paragraph, to the guiding principle in paragraph 9.5 of the Commentary on Article 1. In such a case, there will be no conflict with the treaty provisions if the benefits of the treaty are denied under bothparagraph 7 (or this guiding principle) and relevant domestic specific anti-abuse rules. Domestic specific anti-abuse rules, however, are often drafted with reference to objective facts, such as the existence of a certain level of shareholding or a certain debt-equity ratio. Whilst this facilitates their application and provide greater certainty, it may sometimes result in the application of such a rule in a case where the rule conflicts with a provision of the Convention and where paragraph 7 does not apply to deny the benefits of that provision (and where the guiding principle of paragraph 9.5 of the Commentary on Article 1 also does not apply). In such a case, the Convention will not allow the application of the domestic rule to the extent of the conflict. An example of such a case would be where a domestic law rule that State A adopted to prevent temporary changes of residence for tax purposes would provide for the taxation of an individual who is a resident of State $B$ on gains from the alienation of property situated in a third State if that individual was a resident of State $A$ when the property was acquired and was a resident of State $A$ for at least seven of the 10 years preceding the alienation. In such a case, to the extent that paragraph 5 of Article 13 would prevent the taxation of that individual by State $A$ upon the alienation of the property, the Convention would prevent the application of that domestic rule unless the benefits of the paragraph 5 of Article 13 could be denied, in that specific case, under paragraph 7 (or the guiding principle in paragraph 9.5 of the Commentary on Article 1).

10. Fourth, the application of tax treaty provisions may be denied under judicial doctrines or principles applicable to the interpretation of the treaty (see paragraph 13 below). In such a case, there will be no conflict with the treaty provisions if the benefits of the treaty are denied under both a proper interpretation of the treaty and as result of the application of domestic specific anti-abuse rules. Assume, for example, that the domestic law of State $A$ provides for the taxation of gains 
derived from the alienation of shares of a domestic company in which the alienator holds more than 25 per cent of the capital if that alienator was a resident of State $A$ for at least seven of the 10 years preceding the alienation. In year 2, an individual who was a resident of State $A$ for the previous 10 years becomes a resident of State B. Shortly after becoming a resident of State $B$, the individual sells the totality of the shares of a small company that he previously established in State A. The facts reveal, however, that all the elements of the sale were finalised in year 1 , that an interest-free "loan" corresponding to the sale price was made by the purchaser to the seller at that time, that the purchaser cancelled the loan when the shares were sold to the purchaser in year 2 and that the purchaser exercised de facto control of the company from year 1. Although the gain from the sale of the shares might otherwise fall under paragraph 5 of Article 13 of the State A-State B treaty, the circumstances of the transfer of the shares are such that the alienation in year 2 constitutes a sham within the meaning given to that term by the courts of State A. In that case, to the extent that the sham transaction doctrine developed by the courts of State A does not conflict with the rules of interpretation of treaties, it will be possible to apply that doctrine when interpreting paragraph 5 of Article 13 of the State AState B treaty, which will allow State $A$ to tax the relevant gain under its domestic law rule.

General legislative anti-abuse rules

11. Many countries have included in their domestic law a legislative anti-abuse rule of general application intended to prevent abusive arrangements that are not adequately dealt with through specific antiabuse rules or judicial doctrines.

12. The application of such rules also raises the question of a possible conflict with the provisions of a tax treaty. In the vast majority of cases, however, no such conflict will arise for the reasons presented in paragraphs 7 and 8 above as regards specific domestic anti-abuse rules. In addition, where the main aspects of these domestic general anti-abuse rules are in conformity with the guiding principle of paragraph 9.5 of the Commentary on Article 1 and are therefore similar to the main aspects of paragraph 7, which incorporates this guiding principle, it is clear that no conflict will be possible since the relevant domestic general anti-abuse rule will apply in the same circumstances in which the benefits of the Convention would be denied under paragraph 7, or, in the case of a treaty that does not include that paragraph, to the guiding principle in paragraph 9.5 of the Commentary on Article 1. 
Judicial doctrines that are part of domestic law

13. In the process of interpreting tax legislation in cases dealing with tax avoidance, the courts of many countries have developed a number of judicial doctrines or principles of interpretation. These include doctrines such as substance over form, economic substance, sham, business purpose, step-transaction, abuse of law and fraus legis. These doctrines and principles of interpretation, which vary from country to country and evolve over time based on refinements or changes resulting from subsequent court decisions, are essentially views expressed by courts as to how tax legislation should be interpreted. Whilst the interpretation of tax treaties is governed by general rules that have been codified in Articles 31 to 33 of the Vienna Convention on the Law of Treaties, these general rules do not prevent the application of similar judicial doctrines and principles to the interpretation of the provisions of tax treaties. If, for example, the courts of one country have determined that, as a matter of legal interpretation, domestic tax provisions should apply on the basis of the economic substance of certain transactions, there is nothing that prevents a similar approach from being adopted with respect to the application of the provisions of a tax treaty to similar transactions. This is illustrated by the example in paragraph 10 above.

50. Two specific issues related to the interaction between treaties and specific domestic anti-abuse rules are discussed below. The first issue deals with domestic anti-abuse rules found in the domestic law of one State that are aimed at preventing avoidance arrangements entered into by residents of that State. The second issue, which is indirectly related to the first one, deals with the application of tax treaties to so-called departure or exit taxes.

a) Application of tax treaties to restrict a Contracting State's right to tax its own residents

51. The majority of the provisions included in tax treaties are intended to restrict the right of a Contracting State to tax the residents of the other Contracting State. In some limited cases, however, it has been argued that some provisions that are aimed at the taxation of non-residents could be interpreted as limiting a Contracting State's right to tax its own residents. Such interpretations have been rejected in paragraph 6.1 of the Commentary on Article 1, which deals with a Contracting State's right to tax partners who are its own residents on their share of the income of a partnership that is treated as a resident of the other Contracting State, as well as in paragraph 23 of the same Commentary, which addresses the case of controlled foreign 
companies rules (see also paragraph 14 of the Commentary on Article 7, which deals with the same issue).

52. It was concluded that the principle reflected in paragraph 6.1 of the Commentary on Article 1 should be applicable to the vast majority of the provisions of the Model Tax Convention in order to prevent interpretations intended to circumvent the application of a Contracting State's domestic anti-abuse rules (as illustrated by the example of controlled foreign companies rules). This corresponds to the practice long followed by the United States in its tax treaties, where a so-called "saving clause",13 confirms the Contracting States' right to tax their residents (and citizens, in the case, of the United States) notwithstanding the provisions of the treaty except those, such as the rules on relief of double taxation, that are clearly intended to apply to residents.

53. The following are the changes to the Model Tax Convention that are proposed for that purpose:

Add the following paragraph 3 to Article 1 of the Model Tax Convention:

3. This Convention shall not affect the taxation, by a Contracting State, of its residents except with respect to the benefits granted under paragraph 3 of Article 7, paragraph 2 of Article 9 and Articles 19, 20, 23, 24 and 25 and 28.

Add the following paragraphs 26.17 to 26.21 to the Commentary on Article 1 (other consequential changes to the Commentary would be required):

26.17 Whilst some provisions of the Convention (e.g. Articles $23 \mathrm{~A}$ and $23 \mathrm{~B}$ ) are clearly intended to affect how a Contracting State taxes its own residents, the object of the majority of the provisions of the Convention is to restrict the right of a Contracting State to tax the residents of the other Contracting State. In some limited cases, however, it has been argued that some provisions could be interpreted as limiting a Contracting State's right to tax its own residents in cases where this was not intended (see, for example, paragraph 23 above, which addresses the case of controlled foreign companies provisions).

26.18 Paragraph 3 confirms the general principle that the Convention does not restrict a Contracting State's right to tax its own residents except where this is intended and lists the provisions with respect to which that principle is not applicable. 
26.19 The exceptions so listed are intended to cover all cases where it is envisaged in the Convention that a Contracting State may have to provide treaty benefits to its own residents (whether or not these or similar benefits are provided under the domestic law of that State). These provisions are:

- Paragraph 3 of Article 7, which requires a Contracting State to grant to an enterprise of that State a correlative adjustment following an initial adjustment made by the other Contracting State, in accordance with paragraph 2 of Article 7, to the amount of tax charged on the profits of a permanent establishment of the enterprise.

- Paragraph 2 of Article 9, which requires a Contracting State to grant to an enterprise of that State a corresponding adjustment following an initial adjustment made by the other Contracting State, in accordance with paragraph 1 of Article 9, to the amount of tax charged on the profits of an associated enterprise.

- Article 19, which may affect how a Contracting State taxes an individual who is resident of that State if that individual derives income in respect of services rendered to the other Contracting State or a political subdivision or local authority thereof.

- Article 20, which may affect how a Contracting State taxes an individual who is resident of that State if that individual is also a student who meets the conditions of that Article.

- Article 23, which requires a Contracting State to provide relief of double taxation to its residents with respect to the income that the other State may tax in accordance with the Convention (including profits that are attributable to a permanent establishment situated in the other Contracting State in accordance with paragraph 2 of Article 7).

- Article 24, which protects residents of a Contracting State against certain discriminatory taxation practices by that State (such as rules that discriminate between two persons based on their nationality).

- Article 25, which allows residents of a Contracting State to request that the competent authority of that State consider cases of taxation not in accordance with the Convention. 
- $\quad$ Article 28, which may affect how a Contracting State taxes an individual who is resident of that State when that individual is a member of the diplomatic mission or consular post of the other Contracting State.

26.20 The list of exceptions included in paragraph 3 should include any other provision that the Contracting States may agree to include in their bilateral convention where it is intended that this provision should affect the taxation, by a Contracting State, of its own residents. For instance, if the Contracting States agree, in accordance with paragraph 27 of the Commentary on Article 18, to include in their bilateral convention a provision according to which pensions and other payments made under the social security legislation of a Contracting State shall be taxable only in that State, they should include a reference to that provision in the list of exceptions included in paragraph 3.

26.21 The term "resident", as used in paragraph 3 and throughout the Convention, is defined in Article 4. Where, under paragraph 1 of Article 4, a person is considered to be a resident of both Contracting States based on the domestic laws of these States, paragraphs 2 and 3 of that Article determine a single State of residence for the purposes of the Convention. Thus, paragraph 3 does not apply to an individual or legal person who is a resident of one of the Contracting States under the laws of that State but who, for the purposes of the Convention, is deemed to be a resident only of the other Contracting State.

\section{b) Departure or exit taxes}

54. In a number of States, liability to tax on some types of income that have accrued for the benefit of a resident (whether an individual or a legal person) is triggered in the event that the resident ceases to be a resident of that State. Taxes levied in these circumstances are generally referred to as "departure taxes" or "exit taxes" and may apply, for example, to accrued pension rights and accrued capital gains.

55. To the extent that the liability to such a tax arises when a person is still a resident of the State that applies the tax and does not extend to income accruing after the cessation of residence, nothing in the Convention, and in particular in Articles 13 and 18, prevents the application of that form of taxation. Thus, tax treaties do not prevent the application of domestic tax rules according to which a person is considered to have realised pension income, or to have alienated property for capital gain tax purposes, immediately before ceasing to be a resident. The provisions of tax treaties 
do not govern when income is realised for domestic tax purposes (see, for example, paragraphs 3 and 7 to 9 of the Commentary on Article 13); also, since the provisions of tax treaties apply regardless of when tax is actually paid (see, for example, paragraph 12.1 of the Commentary on Article 15), it does not matter when such taxes become payable, provided that the liability to tax arises when the person is still a resident. ${ }^{14}$

56. The application of such taxes, however, creates risks of double taxation where the relevant person becomes a resident of another State which seeks to tax the same income at a different time, e.g. when pension income is actually received or when assets are sold to third parties. This problem, which is the result of that person being a resident of two States at different times and of these States levying tax upon the realisation of different events, is discussed in paragraphs 4.1 to 4.3 of the Commentary on Article $23 \mathrm{~A}$ and $23 \mathrm{~B}$. As indicated in paragraph 4.3 of that Commentary, which addresses a similar example where two States of residence tax the benefit arising from an employee stock-option at different times:

The mutual agreement procedure could be used to deal with such a case.

One possible basis to solve the case would be for the competent authorities of the two States to agree that each State should provide relief as regards the residence-based tax that was levied by the other State on the part of the benefit that relates to services rendered during the period while the employee was a resident of that other State.

57. Based on that approach, a possible basis for solving double taxation situations arising from the application of departure taxes would be for the competent authorities of the two States involved to agree, through the mutual agreement procedure, that each State should provide relief as regards the residence-based tax that was levied by the other State on the part of the income that accrued while the person was a resident of that other State. This would mean that the new State of residence would provide relief for the departure tax levied by the previous State of residence on income that accrued whilst the person was a resident of that other State, except to the extent that the new State of residence would have had source taxation rights at the time that income was taxed (i.e. as a result of paragraphs 2 or 4 of Article 13). States wishing to provide expressly for that result in their tax treaties are free to include provisions to that effect. 


\section{B. Clarification that tax treaties are not intended to be used to generate double non-taxation}

58. The second part of the work mandated by Action 6 was to "clarify that tax treaties are not intended to be used to generate double non-taxation".

59. The existing provisions of tax treaties were developed with the prime objective of preventing double-taxation. This was reflected in the title proposed in both the 1963 Draft Double Taxation Convention on Income and Capital and the 1977 Model Double Taxation Convention on Income and Capital, which was:

Convention between (State A) and (State B) for the avoidance of double taxation with respect to taxes on income and on capital

60. In 1977, however, the Commentary on Article 1 was modified to provide expressly that tax treaties were no intended to encourage tax avoidance or evasion. The relevant part of paragraph 7 of the Commentary read as follows:

The purpose of double taxation conventions is to promote, by eliminating international double taxation, exchanges of goods and services, and the movement of capital and persons; they should not, however, help tax avoidance or evasion.

61. In 2003, that paragraph was amended to clarify that the prevention of tax avoidance was also a purpose of tax treaties. Paragraph 7 now reads as follows:

The principal purpose of double taxation conventions is to promote, by eliminating international double taxation, exchanges of goods and services, and the movement of capital and persons. It is also a purpose of tax conventions to prevent tax avoidance and evasion.

62. In order to provide the clarification required by Action 6, it has been decided to state clearly, in the title recommended by the OECD Model Tax Convention, that the prevention of tax evasion and avoidance is a purpose of tax treaties. It has also been decided that the OECD Model Tax Convention should recommend a preamble that provides expressly that States that enter into a tax treaty intend to eliminate double taxation without creating opportunities for tax evasion and avoidance. Given the particular concerns arising from treaty shopping arrangements, it has also been decided to refer expressly to such arrangements as one example of tax avoidance that should not result from tax treaties. The following are the changes that are proposed to the OECD Model Tax Convention as a result of the work on this aspect of Action 6: 
Replace the Title of the Convention (including its footnote) by the following:

Convention between (State A) and (State B) for the elimination of double taxation with respect to taxes on income and on capital and the prevention of tax evasion and avoidance-Convention between (State A) and (State B) with respect to taxes on income and on capital ${ }^{1}$

$$
\begin{aligned}
& \text { 1. States wishing to do so may follow the widespread practice of } \\
& \text { including in the title a reference to either the avoidance of } \\
& \text { double taxation or to both the avoidance of double taxation and } \\
& \text { the prevention of fiscal evasion. }
\end{aligned}
$$

Replace the heading "Preamble to the Convention" (including its footnote) by the following:

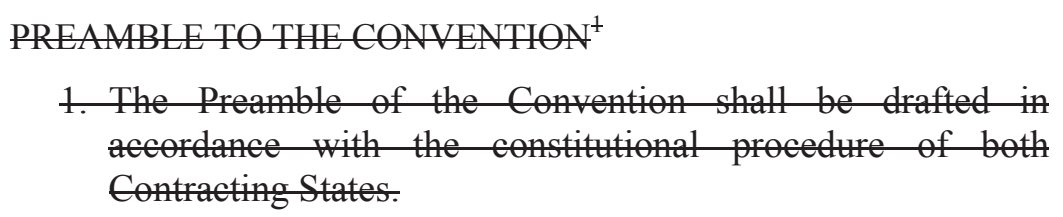

\section{PREAMBLE TO THE CONVENTION}

(State $A)$ and (State B),

Desiring to further develop their economic relationship and to enhance their cooperation in tax matters,

Intending to conclude a Convention for the elimination of double taxation with respect to taxes on income and on capital without creating opportunities for non-taxation or reduced taxation through tax evasion or avoidance (including through treaty-shopping arrangements aimed at obtaining reliefs provided in this Convention for the indirect benefit of residents of third States)

Have agreed as follows:

63. The clear statement of the intention of the signatories to a tax treaty that appears in the above preamble will be relevant to the interpretation and application of the provisions of that treaty. According to the basic rule of interpretation of treaties in Article 31(1) of the Vienna Convention on the Law of Treaties (VCLT), "[a] treaty shall be interpreted in good faith in accordance with the ordinary meaning to be given to the terms of the treaty in their context and in the light of its object and purpose" [emphasis added]. Article $31(2)^{15}$ VCLT confirms that, for the purpose of this basic rule, the context of the treaty includes its preamble. ${ }^{16}$ 
64. The above changes to the Title and Preamble should be supplemented by the following changes to the Introduction to the OECD Model Tax Convention:

Replace paragraphs 2 and 3 of the Introduction by the following:

2. It has long been recognized among the member countries of the Organisation for Economic Co-operation and Development that it is desirable to clarify, standardize, and confirm the fiscal situation of taxpayers who are engaged in commercial, industrial, financial, or any other activities in other countries through the application by all countries of common solutions to identical cases of double taxation. These countries have also long recognized the need to improve administrative co-operation in tax matters, notably through exchange of information and assistance in collection of taxes, for the purpose of preventing tax evasion and avoidance.

3. These are this is -the main purposes of the OECD Model Tax Convention on Income and on Capital, which provides a means of settling on a uniform basis the most common problems that arise in the field of international juridical double taxation. As recommended by the Council of the OECD, ${ }^{1}$ member countries, when concluding or revising bilateral conventions, should conform to this Model Convention as interpreted by the Commentaries thereon and having regard to the reservations contained therein and their tax authorities should follow these Commentaries, as modified from time to time and subject to their observations thereon, when applying and interpreting the provisions of their bilateral tax conventions that are based on the Model Convention.

[Footnote to paragraph 3] 1. See Annex.

Replace paragraph 16 of the Introduction by the following:

16. In both the 1963 Draft Convention and the 1977 Model Convention, the title of the Model Convention included a reference to the elimination of double taxation. In recognition of the fact that the Model Convention does not deal exclusively with the elimination of double taxation but also addresses other issues, such as the prevention of tax evasion and avoidance as well as non-discrimination, it was subsequently-decided, in 1992, to use a shorter title which did not include this reference. This change has been-was made both on the cover page of this publication and in the Model Convention itself. However, it is was understood that the practice of many member countries is-was still to include in the title a reference to either the elimination of double taxation or to both the elimination of double 
taxation and the prevention of fiscal evasion since both approaches emphasized these important purposes of the Convention.

16.1 As a result of work undertaken as part of the OECD Action Plan on Base Erosion and Profit Shifting, in [year] the Committee decided to amend the title of the Convention and to include a preamble. The changes made expressly recognise that the purposes of the Convention are not limited to the elimination of double taxation and that the Contracting States do not intend the provisions of the Convention to create opportunities for non-taxation or reduced taxation through tax evasion and avoidance. Given the particular base erosion and profit shifting concerns arising from treaty-shopping arrangements, it was also decided to refer expressly to such arrangements as one example of tax avoidance that should not result from tax treaties, it being understood that this was only one example of tax avoidance that the Contracting States intend to prevent.

16.2 Since the title and preamble form part of the context of the Convention ${ }^{1}$ and constitute a general statement of the object and purpose of the Convention, they should play an important role in the interpretation of the provisions of the Convention. According to the general rule of treaty interpretation contained in Article 31(1) of the Vienna Convention on the Law of Treaties, "[a] treaty shall be interpreted in good faith in accordance with the ordinary meaning to be given to the terms of the treaty in their context and in the light of its object and purpose."

[Footnote to paragraph 16.2:] 1. See Art. 31(2) VCLT. 


\section{Tax policy considerations that, in general, countries should consider before deciding to enter into a tax treaty with another country}

65. The third part of the work mandated by Action 6 was "to identify the tax policy considerations that, in general, countries should consider before deciding to enter into a tax treaty with another country".

66. It was agreed that having a clearer articulation of the policy considerations that, in general, countries should consider before deciding to enter into a tax treaty could make it easier for countries to justify their decisions not to enter into tax treaties with certain low or no-tax jurisdictions. It was also recognized, however, that there are also many nontax factors that can lead to the conclusion of a tax treaty and that each country has a sovereign right to decide to enter into tax treaties with any jurisdiction with which it decides to do so.

67. In the course of the work on this aspect of Action 6, it was decided that the results of that work should reflect the fact that many of the tax policy considerations relevant to the conclusion of a tax treaty are also relevant to the question of whether to modify (or, ultimately, terminate) a treaty previously concluded in the event that a change of circumstances (such as changes to the domestic law of a treaty partner) raises BEPS concerns related to that treaty.

68. The following are the changes that are proposed to the Introduction of the OECD Model Tax Convention as a result of the work on this aspect of Action 6:

Insert the following paragraphs and new heading immediately after paragraph 15 in the Introduction to the OECD Model Convention (existing section $C$ of the Introduction would become section D).

C. Tax policy considerations that are relevant to the decision of whether to enter into a tax treaty or amend an existing treaty

15.1 In 1997, the OECD Council adopted a recommendation that the Governments of member countries pursue their efforts to conclude bilateral tax treaties with those member countries, and where appropriate with non-member countries, with which they had not yet entered into such conventions. Whilst the question of whether or not to enter into a tax treaty with another country is for each State to decide on the basis of different factors, which include both tax and non-tax considerations, tax policy considerations will generally play a key role in that decision. The following paragraphs describe some 
of these tax policy considerations, which are relevant not only to the question of whether a treaty should be concluded with a State but also to the question of whether a State should seek to modify or replace an existing treaty or even, as a last resort, terminate a treaty (taking into account the fact that termination of a treaty often has a negative impact on large number of taxpayers who are not concerned by the situations that result in the termination of the treaty).

15.2 Since a main objective of tax treaties is the avoidance of double taxation in order to reduce tax obstacles to cross-border services, trade and investment, the existence of risks of double taxation resulting from the interaction of the tax systems of the two States involved will be the primary tax policy concern. Such risks of double taxation will generally be more important where there is a significant level of existing or projected cross-border trade and investment between two States. Most of the provisions of tax treaties seek to alleviate double taxation by allocating taxing rights between the two States and it is assumed that where a State accepts treaty provisions that restrict its right to tax elements of income, it generally does so on the understanding that these elements of income are taxable in the other State. Where a State levies no or low income taxes, other States should consider whether there are risks of double taxation that would justify, by themselves, a tax treaty. States should also consider whether there are elements of another State's tax system that could increase the risk of non-taxation, which may include tax advantages that are ring-fenced from the domestic economy.

15.3 Accordingly, two States that consider entering into a tax treaty should evaluate the extent to which the risk of double taxation actually exists in cross-border situations involving their residents. $A$ large number of cases of residence-source juridical double taxation can be eliminated through domestic provisions for the relief of double taxation (ordinarily in the form of either the exemption or credit method) which operate without the need for tax treaties. Whilst these domestic provisions will likely address most forms of residence-source juridical double taxation, they will not cover all cases of double taxation, especially if there are significant differences in the source rules of the two States or if the domestic law of these States does not allow for unilateral relief of economic double taxation (e.g. in the case of a transfer pricing adjustment made in another State). 
15.4 Another tax policy consideration that is relevant to the conclusion of a tax treaty is the risk of excessive taxation that may result from high withholding taxes in the source State. Whilst mechanisms for the relief of double taxation will normally ensure that such high withholding taxes do not result in double taxation, to the extent that such taxes levied in the State of source exceed the amount of tax normally levied on profits in the State of residence, they may have a detrimental effect on cross-border trade and investment.

15.5 Further tax considerations that should be taken into account when considering entering into a tax treaty include the various features of tax treaties that encourage and foster economic ties between countries, such as the protection from discriminatory tax treatment of foreign investment that is offered by the nondiscrimination rules of Article 24, the greater certainty of tax treatment for taxpayers who are entitled to benefit from the treaty and the fact that tax treaties provide, through the mutual agreement procedure, together with the possibility for Contracting States of moving to arbitration, a mechanism for the resolution of crossborder tax disputes.

15.6 An important objective of tax treaties being the prevention of tax avoidance and evasion, States should also consider whether their prospective treaty partners are willing and able to implement effectively the provisions of tax treaties concerning administrative assistance, such as the ability to exchange tax information, this being a key aspect that should be taken into account when deciding whether or not to enter into a tax treaty. The ability and willingness of a State to provide assistance in the collection of taxes would also be a relevant factor to take into account. It should be noted, however, that in the absence of any actual risk of double taxation, these administrative provisions would not, by themselves, provide a sufficient tax policy basis for the existence of a tax treaty because such administrative assistance could be secured through more targeted alternative agreements, such as the conclusion of a tax information exchange agreement or the participation in the multilateral Convention on Mutual Administrative Assistance in Tax Matters. ${ }^{1}$

[Footnote to paragraph 15.6:] Available at http://www.oecd.org/ctp/exchange-of-tax-information/ENGAmended-Convention.pdf 


\section{Notes}

1. Available at http://www.oecd.org/ctp/BEPSActionPlan.pdf.

2. This report does not deal with situations where countries make a conscious decision not to exercise taxing rights allocated to them by a tax treaty. Such situations are more appropriately dealt with under Action 5 (Counter harmful tax practices more effectively, taking into account transparency and substance).

3. Cases where a resident of the Contracting State in which income originates seeks to obtain treaty benefits (e.g. through a transfer of residence to the other Contracting State or through the use of an entity established in that other State) could also be considered to constitute a form of treaty shopping and are addressed by the recommendations included in this report.

4. Reproduced at page $\mathrm{R}(5)-1$ and $\mathrm{R}(6)-1$ of the full version of the Model.

5. Reproduced at page R(17)-1 of the full version of the Model.

6. See, in particular, Recommendation 9 of the Report:

"that countries consider including in their tax conventions provisions aimed at restricting the entitlement to treaty benefits for entities and income covered by measures constituting harmful tax practices and consider how the existing provisions of their tax conventions can be applied for the same purpose; that the Model Tax Convention be modified to include such provisions or clarifications as are needed in that respect."

7. Paragraph 20 of the Commentary on Article 1.

8. Paragraph 21.4 of the Commentary on Article 1.

9. One assumption that led to the inclusion of paragraph 4 was that Action 5 (Counter harmful tax practices more effectively, taking into account transparency and substance) and Action 8 (Intangibles) of the BEPS Action Plan will address BEPS concerns that may arise from a derivative benefits provision that would apply not only to dividends but also to baseeroding payments such as royalties. The inclusion of paragraph 4 , or 
alternative means of addressing those BEPS concerns, will therefore need to be examined based on the outcome of the work on these Action items.

10. See, for example, the alternative provision suggested in paragraph 42.45 of the Commentary on Article 5, which deals with the splitting-up of contracts in order to circumvent the alternative provision found in paragraph 42.23 .

11. Paragraph 23 of the Commentary on Article 4 of the 1963 Draft Convention.

12. Under the principles of public international law, as codified in Articles 26 and 27 of the Vienna Convention on the Law of Treaties (VCLT), if the application of a domestic anti-abuse rule has the effect of allowing a State that is party to a tax treaty to tax an item of income that that State is not allowed to tax under the provisions of the treaty, the application of the domestic anti-abuse rule would conflict with the provisions of the treaty and these treaty provisions should prevail.

13. The saving clause and its exceptions read as follows in the US Model:

4. Except to the extent provided in paragraph 5, this Convention shall not affect the taxation by a Contracting State of its residents (as determined under Article 4 (Resident)) and its citizens. Notwithstanding the other provisions of this Convention, a former citizen or former long-term resident of a Contracting State may be taxed in accordance with the laws of that Contracting State.

5. The provisions of paragraph 4 shall not affect:

a) the benefits conferred by a Contracting State under paragraph 2 of Article 9 (Associated Enterprises), paragraph 7 of Article 13 (Gains), subparagraph b) of paragraph 1, paragraphs 2, 3 and 6 of Article 17 (Pensions, Social Security, Annuities, Alimony, and Child Support), paragraph 3 of Article 18 (Pension Funds), and Articles 23 (Relief From Double Taxation), 24 (Non-Discrimination), and 25 (Mutual Agreement Procedure); and

b) the benefits conferred by a Contracting State under paragraph 1 of Article 18 (Pension Funds), Articles 19 (Government Service), 20 (Students and Trainees), and 27 (Members of Diplomatic Missions and Consular Posts), upon individuals who are neither citizens of, nor have been admitted for permanent residence in, that State.

14. The addition of the provision referred to in section $a$ ) above will confirm that the provisions of a tax treaty do not restrict a State's right to apply 
departure or exit taxes as long as the liability to tax arises when the person is a resident of that State.

15. "2. The context for the purpose of the interpretation of a treaty shall comprise, in addition to the text, including its preamble and annexes:

(a) Any agreement relating to the treaty which was made between all the parties in connexion with the conclusion of the treaty;

(b) Any instrument which was made by one or more parties in connexion with the conclusion of the treaty and accepted by the other parties as an instrument related to the treaty."

16. The Commentary on the 1966 Draft of the Vienna Convention on the Law of Treaties notes that the International Court of Justice "has more than once had recourse to the statement of the object and purpose of the treaty in the preamble in order to interpret a particular provision" (Draft Articles on the Law of Treaties with commentaries, Report of the International Law Commission to the General Assembly, Yearbook of the International Law Commission, 1966, vol. II, p. 221). 



\section{ORGANISATION FOR ECONOMIC CO-OPERATION AND DEVELOPMENT}

The OECD is a unique forum where governments work together to address the economic, social and environmental challenges of globalisation. The OECD is also at the forefront of efforts to understand and to help governments respond to new developments and concerns, such as corporate governance, the information economy and the challenges of an ageing population. The Organisation provides a setting where governments can compare policy experiences, seek answers to common problems, identify good practice and work to co-ordinate domestic and international policies.

The OECD member countries are: Australia, Austria, Belgium, Canada, Chile, the Czech Republic, Denmark, Estonia, Finland, France, Germany, Greece, Hungary, Iceland, Ireland, Israel, Italy, Japan, Korea, Luxembourg, Mexico, the Netherlands, New Zealand, Norway, Poland, Portugal, the Slovak Republic, Slovenia, Spain, Sweden, Switzerland, Turkey, the United Kingdom and the United States. The European Union takes part in the work of the OECD.

OECD Publishing disseminates widely the results of the Organisation's statistics gathering and research on economic, social and environmental issues, as well as the conventions, guidelines and standards agreed by its members. 


\section{OECD/G20 Base Erosion and Profit Shifting Project Preventing the Granting of Treaty Benefits in Inappropriate Circumstances}

Addressing base erosion and profit shifting is a key priority of governments around the globe. In 2013, OECD and G20 countries, working together on an equal footing, adopted a 15-point Action Plan to address BEPS. This report is an output of Action 6.

Beyond securing revenues by realigning taxation with economic activities and value creation, the OECD/G20 BEPS Project aims to create a single set of consensus-based international tax rules to address BEPS, and hence to protect tax bases while offering increased certainty and predictability to taxpayers. A key focus of this work is to eliminate double non-taxation. However in doing so, new rules should not result in double taxation, unwarranted compliance burdens or restrictions to legitimate cross-border activity.

\section{Contents}

Executive summary

Introduction

A. Treaty provisions and/or domestic rules to prevent the granting of treaty benefits in inappropriate circumstances

B. Clarification that tax treaties are not intended to be used to generate double nontaxation

C. Tax policy considerations that, in general, countries should consider before deciding to enter into a tax treaty with another country

www.oecd.org/tax/beps.htm

Consult this publication on line at $\boldsymbol{h t t p : / / d x . d o i . o r g / 1 0 . 1 7 8 7 / 9 7 8 9 2 6 4 2 1 9 1 2 0 - e n . ~}$

This work is published on the OECD iLibrary, which gathers all OECD books, periodicals and statistical databases.

Visit www.oecd-ilibrary.org for more information.

OECDpublishing www.oecd.org/publishing
ISBN 978-92-64-21906-9

$232014281 \mathrm{P}$

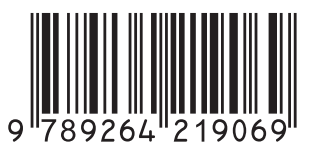

